\title{
The Role of Institutional Investors in Voting: Evidence from the Securities Lending Market The Journal of Finance
}

\author{
Reena Aggarwal, Pedro A. C. Saffi, and Jason Sturgess*
}

\begin{abstract}
This paper investigates voting preferences of institutional investors using the unique setting of the securities lending market. Investors restrict lendable supply and/or recall loaned shares prior to the proxy record date to exercise voting rights. Recall is higher for investors with greater incentives to monitor, for firms with poor performance or weak governance, and for proposals where returns to governance are likely higher. At the subsequent vote, recall is associated with less support for management and more support for shareholder proposals. Our results indicate that institutions value their vote and use the proxy process to affect corporate governance.
\end{abstract}

JEL: G32; G34; G38

Keywords: Proxy Voting, Securities Lending, Institutional Investors, Value of the Vote.

\footnotetext{
* Aggarwal is at the McDonough School of Business, Georgetown University; Saffi is at the Judge School of Business, Cambridge University; and Sturgess is at the Driehaus College of Business, DePaul University. We thank Cam Harvey (the editor), an anonymous Associate Editor, and two anonymous referees for excellent comments. We thank Alon Brav, Susan Christoffersen, Isil Erel, Richard Evans, Slava Fos, Stuart Gillan, Mireia Giné, Denis Gromb, Steve Kaplan, Jose Liberti, Lee Pinkowitz, Gregor Matvos, David Musto, Adam Reed, David Ross, Laura Starks, Astrid Schornick and David Yermack; seminar participants at the Federal Reserve Board, U.S. Securities and Exchange Commission, 10th Cambridge - Princeton Meeting, ICGN 2014 Academic Meeting, 3rd Annual RMA - UNC Academic Forum for Securities Lending Research, American Finance Association 2013, European Finance Association 2011, Western Finance Association 2011, FMA Asia 2011, Drexel Conference on Corporate Governance 2011, DePaul University, Georgetown University, IESE, Università Cattolica del Sacro Cuore, Comisión Nacional del Mercado de Valores, London School of Economics, Temple University, University of Cambridge, Queen Mary, University of Maryland, University of Texas at Austin, Imperial College, INSEAD, University of Sydney, UNSW Australia, Singapore Management University, National University of Singapore, Nanyang Technological University and HKUST for helpful comments. Conversations with several industry participants, particularly, Les Nelson of Goldman Sachs and Judith Polzer of J.P. Morgan helped us to understand the workings of the securities lending market. Doria $\mathrm{Xu}$ and Jiayang $\mathrm{Yu}$ provided excellent research assistance. We gratefully acknowledge a grant from the $\mathrm{Q}$ Group. Saffi acknowledges support from the Spanish Ministry of Science and Innovation under ECO2008-05155 at the Public-Private Sector Research Center at IESE. Aggarwal acknowledges support from the Robert E. McDonough endowment at Georgetown University's McDonough School of Business.
} 


\section{The Role of Institutional Investors in Voting: Evidence from the Securities Lending Market}

Understanding the preferences of institutional investors regarding governance is important for firms trying to attract new investors as well as for policy makers considering the regulation of different governance mechanisms. However, the mechanisms used by institutional investors to impact corporate governance tend to be private and difficult to study.

One key governance mechanism through which institutional investors can exert influence is the proxy voting process. In this paper, we use the unique setting of the securities lending market to study the conditions that prompt institutional investors to influence firm-level governance and the extent to which investors use the proxy voting process to exercise their opinions. Most large pension funds, mutual funds, and other institutional investors have a lending program and consider it to be an important source of revenue, with estimates of $\$ 800$ million in annual revenue for pension funds alone (Grene (2010)). Equity lending transfers voting rights to the borrower, typically hedge funds, and therefore lenders cannot vote shares that are on loan on the voting record

date. ${ }^{1}$ Hence, institutions must decide whether to recall shares or make shares available for borrowing for an associated fee and the transfer of voting rights.

Our study uses a comprehensive daily data set comprised of lendable supply, shares on loan, and the associated borrowing fee for the period 2007-2009. Lendable supply measures the shares made available to borrow by investors with long positions in the stock, and on loan measures borrowing demand, which is the quantity actually lent out. We find a marked reduction in the lendable supply prior to the proxy record date and an increase in borrowing demand and fees around the record date. Furthermore, lendable supply returns to normal levels immediately after the record date, consistent with institutions restricting and/or recalling their loaned shares to exercise their voting rights and resuming lending immediately after the record date. 
We make five contributions. First, our results illustrate that institutional investors value the right to vote. Analyzing the lendable supply dynamics of the equity lending market around voting record dates reveals that institutional investors recall shares to retain voting rights. ${ }^{2}$ This finding shows that institutional investors value their vote and use the proxy process as an important channel for affecting corporate governance. In addition, we show that borrowing demand and fee increase around the record day. Second, we find that institutional investors do not all value their voting rights in the same way, with considerable heterogeneity in the preferences. Third, we show that the decision to recall shares on the voting record date also varies based on firm and proposal characteristics, which typically affect the value of control rights. Fourth, we propose a metric to quantify the value of the vote and find that lenders of shares place a higher value on their vote than borrowers. Finally, we show that share recall is associated with less support for management in the subsequent voting outcome.

The heterogeneity in recall of shares shows that institutional investors systematically differ in their desire to exert governance via proxy voting. For example, Shleifer and Vishny (1986) model the blockholder's free-rider problem and show that the willingness of a shareholder to intervene will increase with the size of their stake, the value creation stemming from such intervention, but decrease with the cost of monitoring. ${ }^{3}$ Consequently, institutional investors should not be expected to recall shares en-masse on all record dates. The recall by institutional investors should differ along several dimensions including their ownership stake, investment philosophy, investment time horizon, fiduciary responsibility, ability or incentives to engage with management, and/or invest in private information required for effective monitoring (e.g., Maug (1998), Kahn and Winton (1998) and Edmans (2009)). As an empirical example, Matvos and Ostrovsky (2010) find systematic heterogeneity in voting behavior even across mutual funds. 
While we do not know the identity of the lenders and the borrowers, we study the heterogeneity in investors' voting preferences by observing the differences in recall between firms that have a higher proportion of ownership by certain types of investors. We classify institutional ownership based on categories used previously in the literature (e.g., Bushee (1998, 2001), Bushee and Goodman (2007), and Chen, Harford, and Li (2007)) and examine blockholdings in aggregate, since these investors should have the greatest incentive to intervene through the proxy process (Maug (1998)), and those held by four types of investors: mutual funds, banks and insurance companies, pensions and endowments, and long-term investors. For aggregate blockholdings and each of the four categories, we find that the recall/restriction in lendable supply is significantly higher for firms with higher ownership relative to firms with low ownership. When examining borrowing demand, the difference is never statistically significant. Our results provide insights into the preferences of institutional investors, and suggest that institutional investors do not all have the same motivation to be active in corporate governance.

We also examine asymmetric changes in lendable supply and borrowing demand based on underlying firm characteristics and types of proposal on the ballot. Firms with poor performance, weaker governance, and smaller size exhibit higher recall of shares on the record date. Additionally, recall is higher for record dates associated with meetings that have important proposals on the ballot related to non-routine items, compensation, anti-takeover, and corporate control. For example, the recall effect is almost $40 \%$ higher for record dates with corporate controlrelated proposals than those without. These results support the hypothesis that shareholders value the vote and are keener to vote when it is more "important" to do so.

When we examine the subsequent vote outcome, we find that higher recall of lendable supply is associated with less support for management proposals, such as those relating to 
compensation and corporate control, and more support for shareholder proposals. In additional tests, we focus on the voting behavior of mutual funds, since these institutional investors provide a large fraction of lendable supply. Mutual funds are significantly less likely to vote in favor of contentious proposals where recall in lendable supply is greater and the proxy advisory firm ISS recommends voting against the proposal. These results on mutual fund voting address any concern that recall could be negatively associated with support because institutions recall shares to vote with management when support for management is low.

There are several reasons why examining recall in the lending market, as opposed to the borrowing fee, improves our understanding about institutional investor voting preferences. Kolasinski, Reed, and Ringgenberg (2013) show that the supply of lendable shares is essentially flat in the equity lending market, and Prado, Saffi and Sturgess (2014) document that this market clears with high levels of slack lendable supply for the average firm. Therefore, borrowing fee can be insensitive to both changes in demand and supply. Consequently, examining changes in the borrowing fee alone may underestimate the value of the vote, and could even result in concluding that the value of the vote is close to zero. To isolate record date effects due to changes in preferences for supplying shares from changes due to demand-side effects, we use an instrumental variables setup. One of our major contributions is to show that it is important to analyze both the lendable supply and the loan demand side of the market.

The issues we examine are particularly relevant for a period that has seen increased emphasis on both shareholder activism and proxy voting. Voting provides an important mechanism for shareholders to affect firm-level corporate governance and policies. The paper proceeds as follows. Section I provides a literature review. Section II provides background on the securities lending market. Section III describes the data on proxy voting, securities lending, and other firm- 
level corporate attributes. In Section IV, we discuss our methodology and identification strategy. Section V contains the main empirical results. Section VI presents results of our empirical findings on voting outcomes and the role of lendable supply. Section VII concludes.

\section{Literature Review}

Prior research has attempted to examine the preferences of institutional investors based on inferences of corporate governance attributes deemed important to institutional investors. Gillan and Starks (2000) study the effectiveness of shareholder activism in the U.S. Other studies have found that institutional investors affect CEO turnover (Parrino, Sias, and Starks (2003) and Helwege, Intintoli, and Zhang (2012)), anti-takeover amendments (Brickley, Lease, and Smith (1988)), executive compensation (Hartzell and Starks (2003)), and mergers (Gaspar, Massa, and Matos (2005) and Chen, Harford, and Li (2007)). In an analysis of 23 countries, Aggarwal, Erel, Ferreira, and Matos (2011) find that changes in institutional ownership are positively associated with subsequent changes in firm-level governance, but the opposite is not true. Cuñat, Gine and Guadalupe (2012) show that passing a governance provision is associated with an increase in shareholder value, and more so when proposals are sponsored by institutions.

Maug (1998) and Kahn and Winton (1998) show how large stakes bias investors towards more shareholder activism. Edmans (2009) argues that the effectiveness of activism depends on the threat to sell shares and exit the firm, which in turn is greater for investors with larger stakes. Empirically Gillan and Starks (2000) examine the reaction of different types of shareholders to proposals through their voting behavior. Duan and Jiao (2014) show that mutual funds with smaller ownership blocks and shorter investment horizons are more likely to exit rather than vote against management. Bushee, Carter and Gerakos (2013) show that institutional preferences about governance and voting vary based on several factors including investment philosophy and 
fiduciary responsibility. Preferences may also depend on other factors such as investment horizon and economic stakes.

In a survey of institutional investors, McCahery, Sautner, and Starks (2011) find that corporate governance is important to institutional investors, and many institutions are willing to engage in shareholder activism via the proxy process. Recent papers such as Brav, Jiang, Partnoy, and Thomas (2008); Clifford (2008); and Klein and Zur (2009) study activism by individual funds, such as pension funds or hedge funds. Fos (2011) shows that proxy contests play a role in disciplining managers, while Gantchev (2013) finds that proxy contests are costly and that monitoring costs wipe out activist returns, on average. Illiev and Lowry (2013) conclude that certain types of funds invest considerable resources examining firm-level governance issues, and then voting accordingly.

Some controversy exists in the literature regarding how changes in the supply and demand for lending shares around the record date affect the borrowing fee and what these changes imply in terms of the value of a vote. Christoffersen, Géczy, Musto, and Reed (2007) use 1998-1999 data from a large lending agent to examine borrowing demand and fees aspects of the securities lending market around a proxy vote. They find a marginally significant increase in borrowing fee around the proxy record date. The authors conclude that the price of a vote is zero because investors are not selling their votes but willingly letting them go, and speculate that this result is due to information asymmetry. Examining the change in fee alone, we find that fee increases by two basis points on the record date, approximately three times as large as the value found by Christoffersen, Géczy, Musto, and Reed (2007). Using option prices, Kalay, Karakas, and Pant (2014), find the value of voting rights for the average firm to be $0.16 \%$ of the stock price with an average option 
maturity of 38 days. Moser, Van Ness, and Van Ness (2013) examine securities lending activity around proxy voting record date for potential abuse and empty voting.

\section{Securities Lending Market}

Securities lending is a transaction in which the beneficial owner of the securities, normally a large institutional investor such as a pension fund or mutual fund, agrees to lend its securities to a borrower, such as a hedge fund, in exchange for collateral consisting of cash and/or other securities. ${ }^{4}$ Although lenders refer to these shares as being "on loan", the lender actually transfers ownership and voting rights. Shares may be borrowed for a variety of reasons, including short selling, or for trading strategies such as convertible bond arbitrage and dividend tax-arbitrage, and possibly for empty voting. ${ }^{5}$ The lender earns a spread by investing the collateral in low-risk shortterm securities. In a typical U.S. loan, the collateral is $102 \%$ on domestic securities and $105 \%$ for international securities. The increased interest in proxy voting and securities lending has resulted in fund boards now paying attention not only to the fee received from a securities lending program but also to whether the securities are being loaned to "responsible" borrowers. According to a survey of institutional investors by ISS, $37.9 \%$ of the respondents stated that a formal policy on securities lending is part of their proxy voting policy. ${ }^{6}$ Some funds require a total recall of shares, while others weigh the lost revenue against the benefits of voting on a case-by-case basis. Below, we provide some examples from funds' proxy voting guidelines.

\section{Putnam Funds}

"The funds' have requested that their securities lending agent recall each domestic issuer's voting securities that are on loan, in advance of the record date for the issuer's shareholder meetings, so that the funds may vote at the meetings." 7 


\section{TIAA-CREF}

"Even after we lend the securities of a portfolio company, we continue to monitor whether income from lending fees is of greater value than the voting rights that have passed to the borrower. Using the factors set forth in our policy, we conduct an analysis of the relative value of lending fees versus voting rights in any given situation. We will recall shares when we believe the exercise of voting rights may be necessary to maximize the long-term value of our investments despite the loss of lending fee revenue." 8

The SEC requires funds to recall shares for "material" events but has not defined materiality. In a survey by ISS, $92.3 \%$ of the respondents indicated that mergers and acquisitions were the most important reason to recall shares. ${ }^{9}$ One of the challenges to recalling shares is that shareholders typically do not receive the proxy material until after the record date. However, in order to vote, institutions must recall the shares by the record date.

\section{Data}

\section{A. Securities Lending Descriptive Statistics}

We obtain a proprietary equity lending data set from Data Explorers (now Markit) for the period January 2007 to December 2009. They collect this information daily from 125 large custodians and 32 prime brokers in the securities lending industry. Our data covers more than $85 \%$ of the securities lending market. While there are 4,333 firms in the equity lending sample, the proxy voting data limits the analysis to the constituents of the Russell 3000 index. As of December 2009 , there was $\$ 1.55$ trillion available to lend, out of which $\$ 113$ billion was actually lent out and would be considered as being on loan. Saffi and Sigurdsson (2011) provide a detailed description of the data. 
The main dependent variables in our study are defined as follows: lendable supply (SUPPLY) is the dollar value of supply available on a given day relative to a firm's market capitalization; loan quantity $(O N L O A N)$ is the dollar value of shares on loan relative to market capitalization; utilization rate (UTILIZATION) is ONLOAN divided by SUPPLY; and borrowing fee $(F E E)$ is the average transaction-weighted rate reported by Data Explorers and expressed in basis points (bps) per annum. Firms that have a fee greater than 100 basis points (1\%) are commonly considered to be SPECIAL. Such firms are more closely watched by investors and are more expensive to borrow.

In Table 1, we present descriptive statistics for the equity lending market. On average, $23.78 \%$ of a firm's market capitalization is available for lending, with $4.06 \%$ being on loan and resulting in a utilization rate of $17.78 \%$. The minimum and maximum values of SUPPLY (winsorized at the $1 \%$ level) are $1.65 \%$ and $48.57 \%$, respectively. ONLOAN varies from a high of $20.49 \%$ to a low of $0.01 \%$. Some firms are heavily borrowed while others are not borrowed at all. UTILIZATION is as high as $69 \%$ in our sample.

[Table 1 around here]

The mean annualized fee is $48.3 \mathrm{bps}$, implying that it is very cheap, on average, to borrow shares. However, this cost can quickly rise for firms in high demand reaching a maximum of 1,114 bps in our winsorized sample. About $9 \%$ of the firms have a fee greater than 100 basis points and are considered to be "on special". The mean and median number of days for which loans are outstanding is 16 days and one day, respectively. Most loans are "open ended" and rolled over every day without a specific maturity date.

Figure 1 plots lendable supply, loan demand, utilization, and borrowing fees for the period starting 30 days before the record date and ending 30 days after the record date. We define the 
record date (day 0 ) as the event date. For our 7,415 voting record dates, the average time between the record date and the shareholder meeting is 53 days. The supply of shares available to lend as a fraction of market capitalization starts to decrease about 20 days before a vote and is at its lowest point on day 0, the record date. On average, $S U P P L Y$ is equal to $24.09 \%$ on day -30 and reduces to $22.16 \%$ by the record date. This drop in supply is consistent with institutions restricting or recalling their shares at the time of a vote. On the first day after the record date, SUPPLY returns to pre-event levels in line with institutions not wanting to lose revenue from lending.

[Figure 1 around here]

The results suggest that institutions start restricting supply in advance of the proxy record date to ensure that shares can be recalled and that they can exercise the vote. In practice, institutions are generally advised to allow two weeks for a recall prior to a proxy vote, and possibly longer if the firm is "special". Consistent with industry practice, we find that the drop in lendable supply starts to occur about two weeks before the record. ${ }^{10}$ Institutions might also recall shares in advance to provide sufficient notice to borrowers, thus alleviating possible problems for borrowers to find shares and improving an institution's reputation as a stable and reliable lender. ${ }^{11}$

Examining the plot for borrowing demand (ONLOAN) shows a small increase around the record date. On day -30 , on average, $4.10 \%$ of a firm's market capitalization is on loan, and by the record date it grows to $4.13 \%$, increasing by only $0.03 \%$ of a firm's market capitalization. Finally, UTILIZATION and FEE both increase in the 20 days prior to the record date. This result adds insight to Blocher, Reed and Van Wesep (2013), who argue that shifts in supply matters only for firms on special by revealing that supply shifts become important even at relatively low levels of utilization.

\section{B. Other Firm-Level Data}


We use CRSP to obtain share price (PRICE), market capitalization (SIZE), turnover (TURNOVER), and bid-ask spread (SPREAD). We use only common shares with price over $\$ 1$, and further merge the data to Compustat and collect data on book equity (EQUITY) to calculate the book-to-market equity ratio $(B M)$. We exclude closed-end funds, American Depositary Receipts (ADRs) and real estate investment trusts (REITs). We obtain ownership data from the Thomson Reuters CDA/Spectrum database on SEC 13F filings. The 13F filings must be reported on a quarterly basis by all investment companies and professional money managers with assets over \$100 million under management. For each firm, we calculate total institutional ownership as a percentage of market capitalization (INST) and institutional ownership concentration (INST $C O N C$ ), measured as the Hirschman-Herfindahl index normalized between zero and one. We use firm-level corporate governance index GOV41 as in Aggarwal, Erel, Ferreira, and Matos (2011). GOV41 assigns a value of one to each of the 41 governance attributes if the company meets minimally acceptable governance guidelines on that attribute and zero otherwise. We classify institutional ownership into five groups: (1) all 5\% or more blockholders; (2) bank blockholders includes banks and insurance companies; (3) mutual funds blockholders includes investment companies; (4) pensions and endowments; and (5) long term blockholders are those that hold their stake for more than one year. ${ }^{12,13}$

\section{Proxy Voting Descriptive Statistics}

Proxy voting analysis examines 56,220 proposals for 7,415 record-dates obtained from ISS. The proxy voting data cover the Russell 3000 index constituents and include proposal-level characteristics such as proposal description, sponsor, management's recommendation, ISS's recommendation, threshold for the proposal to pass, votes cast, and voting result. 
We present proxy voting characteristics in Panel A of Table 3. On average, $86.62 \%$ of votes are cast on proxy proposals, with $91.86 \%$ of those votes being in favor and only $7.54 \%$ against. This overwhelming majority in favor of proposals is reflected in the $70.16 \%$ vote margin by which they pass. We create different categories of proposals, with the explicit aim of exploring those that might be considered as contentious, based on disagreement between different parties, and those that are associated with significant events. First, we classify proposals as routine and non-routine. NYSE Rule 452 outlines non-routine proxy proposals as those in which broker voting is not allowed. Examples include proposals relating to anti-takeover provisions, stock capitalization and mergers. Second, we examine proposals relating specifically to anti-takeover provisions $(G$ INDEX) included in the G-Index developed by Gompers, Ishi, and Metrick (2003), compensation proposals $(C O M P)$, and those that relate to mergers/proxy contests (CORP CONTROL).

In Panel B of Table 3 we describe the voting outcome of non-routine proposals, which comprise $12.25 \%$ of the total sample. These proposals have almost three times more votes cast against the proposal than found for the total sample. Almost $60 \%$ of non-routine proposals are related to compensation. Shareholder-sponsored proposals are a much smaller subset (only $25.56 \%$ ) and usually fail to pass, receiving an average of $40 \%$ of FOR votes, although when ISS is in favor of the proposal the average proportion of FOR votes increase to 46.17\%. Examples of shareholder-sponsored proposals include Say on Pay; requests that the firm provide cumulative voting; reduce supermajority voting; require independent chairman of board; require a majority vote for the election of directors; and declassify the board of directors. We also provide descriptive statistics on non-routine proposals that are likely to attract most attention from investors. Proposals relating to compensation, anti-takeover, and corporate control receive far more negative votes than the average for all proposals discussed earlier. 
[Table 3 around here]

\section{Methodology}

\section{A. Instrumental Variables Framework}

Our empirical strategy estimates quantity variables (i.e., SUPPLY or ONLOAN) as a function of price (FEE), a record date dummy (RDATE), and other controls. We employ the instrumental variables estimator developed by Angrist, Graddy and Imbens (2000) to infer the price sensitivity of SUPPLY and ONLOAN. Kolasinski, Reed and Ringgenberg (2013) use a similar approach to estimate how the supply schedule varies with proxies for searching frictions in the equity lending market. If a restriction in supply results in a higher fee, and these higher prices result in lower demand, it is relatively straightforward to show that standard OLS estimates that ignore endogeneity will result in downward bias in estimates for record date demand shifts. Similarly, ignoring endogeneity can also lead to a downward bias in lendable supply shifts at the record date due to changes in demand. Therefore, we estimate the following IV regression for lendable supply $(S U P P L Y)$ in the $(-30,+30)$ days period around the record date:

$$
\begin{aligned}
& 1^{\text {st }} \text { stage: } \quad F E E_{i, t}=\alpha_{i}^{F 1}+\alpha_{t}^{F 1}+\gamma^{F 1} \text { RDATE }_{i, t}+\theta_{2}^{F 1} \operatorname{INSTRU}_{S_{i, t}}+\delta^{F 1} \operatorname{Controls}_{i, t}+\varepsilon_{i, t}^{F 1} \\
& 2^{\text {nd }} \text { stage: SUPPLY } Y_{i, t}=\alpha_{i}^{S}+\alpha_{t}^{S}+\gamma^{S} R D A T E_{i, t}+\beta_{1}^{S} F E E_{i, t}+\beta_{2}^{S} R D A T E * F E E_{i, t}++\delta^{S} \operatorname{Controls}_{i, t}+\varepsilon_{i, t}^{S} .
\end{aligned}
$$

For borrowing demand $(O N L O A N)$ we estimate:

$1^{\text {st }}$ stage: $\quad F E E_{i, t}=\alpha_{i}^{F 2}+\alpha_{t}^{F 2}+\gamma^{F 2} R D A T E_{i, t}+\theta_{2}^{F 2} I_{N S T R U_{D i, t}}+\delta^{F 2}$ Controls $_{i, t}+\varepsilon_{i, t}^{F 2}$,

$2^{\text {nd }}$ stage: $\mathrm{ONLOAN}_{i, t}=\alpha_{i}^{D}+\alpha_{t}^{D}+\gamma^{D} R D A T E_{i, t}+\beta_{1}^{D} F E E_{i, t}+\beta_{2}^{D} R D A T E * F E E_{i, t}+\delta^{D}$ Controls $_{i, t}+\varepsilon_{i, t}^{D}$,

where INSTRU $U_{D}$ and INSTRU $U_{S}$ are the exogenous instruments used to identify FEE in the second stage for each of the two quantity variables (i.e., ONLOAN and SUPPLY), $\alpha_{i}$ and $\alpha_{t}$ are firm and year fixed effects respectively, $\beta_{2}$ represents the elasticity on the record date and $\gamma$ represents the shift in quantity on the record date. ${ }^{14}$ We include firm and year fixed effects to ensure robustness to heteroskedasticity as well common year-specific shocks. 
The estimates above compare record date shifts in lendable supply and borrowing demand with non-record date levels for the same firm. We capture not only the recall in lendable supply and increase in borrowing demand on the record date $\left(\gamma^{S}\right.$ and $\left.\gamma^{D}\right)$ but also changes in the fee-elasticity of SUPPLY and ONLOAN on the record date $\left(\beta_{2}^{S}\right.$ and $\left.\beta_{2}^{D}\right) .{ }^{15}$ Employing an IV framework to examine lendable supply, which measures the quantity of shares made available to borrow, and borrowing demand, which measures the quantity of shares borrowed, at the record date is similar to that used in the labor market. ${ }^{16}$ Wages are equivalent to lending fees $(F E E)$, the employment rate is equivalent to loan demand (ONLOAN), and the size of the labor force is equivalent to lendable supply (SUPPLY). For example, Eissa and Liebman (1996) study how changes in the Earned Income Tax Credit (EITC) affects labor force participation and hours worked of single mothers. In our context, the RDATE variable is equivalent to a dummy controlling for EITC tax change in 1986, while SUPPLY is equivalent to labor market participation. These tax changes are expected to not only to affect the level of quantity supplied (i.e., SUPPLY in our case) but also the impact of wages on participation rates (i.e., similar to our estimates for the $R D A T E^{*} F E E$ coefficient).

\section{B. Choice of Instruments}

We start by introducing the instruments necessary to implement the empirical strategy described earlier. Identification requires finding instruments that are exogenously related to FEE but unrelated to the error term in the SUPPLY and ONLOAN equations. For example, in equation (4) for $O N L O A N$ we need variables that affect FEE but not demand, such that we can find estimated $\widehat{F E E}$ and $R D A \widehat{T E *} F E E$ values that are uncorrelated with the error term $\varepsilon_{i, t}^{D}$. More specifically, we instrument demand to map out changes in lendable supply (i.e., equations (1) and (2)) and instrument lendable supply to map out changes in borrowing demand to control for the endogeneity between quantity and price (i.e., equations (3) and (4)). 
This approach requires valid instruments that satisfy the exclusion restriction, that is, the instrument must not have any direct impact on the dependent variable or through omitted variables. Thus, we need to identify variables that affect FEE through changes in ONLOAN (SUPPLY) but are unrelated to SUPPLY (ONLOAN).

To identify SUPPLY, we initially consider the following variables that capture demandrelated shocks to FEE: hedging demand, earnings surprise, and discretionary accruals. Hedging Demand is proposed by Hwang, Liu and Xu (2013), who argue that short selling can help correct under-pricing of firms by facilitating the hedging of industry risk. If other firms in the same industry become under-valued, arbitrageurs should purchase the under-valued firms and short substitute securities. Thus, we expect the demand for shorting stock $i$ to be high when the demand for going long shares of peers, $j$, is high. Underpricing is measured as low relative cumulative returns in the previous year, where relative returns are defined as the equal-weighted cumulative return in the past 252 days of related firms (excluding the firm's own returns) with the same fourdigit GICS industry classification code.

Our second instrument is the standardized unexpected earnings measure, $S U E$, defined as the last quarter's earnings surprise relative to analysts' median earnings forecasts (Livnat and Mendenhall (2006)). Christophe, Ferri and Angel (2004) show that short interest in periods without earnings announcements is higher for stocks with low SUE, leading us to expect that demand is negatively related to $S U E$. Furthermore, short selling does not increase prior to earnings announcements. Ke and Ramalingegowda (2005) show that high-turnover institutional investors trade to exploit post earnings announcement drift, but that "dedicated" and "quasi-indexing" institutions, both long-horizon investors, do not. Hence, we do not expect that variation in $S U E$ will affect equity lendable supply via changes in the portfolio of long-term institutions. 
Finally, following Kolasinski, Reed, and Ringgenberg (2013), we consider discretionary accruals, ACCRUALS, as computed in Sloan (1996), as a potential instrument. Discretionary accruals constitute a decision by management to shift earnings from one period to another, and are therefore temporary in nature. Further, they tend to be short-term and prior literature finds that short selling is positively related to discretionary accruals (e.g., Kolasinski et al (2007)).

To identify $O N L O A N$, we consider two variables to instrument FEE that should be unrelated to loan demand: passive ownership (PASSIVE) and institutional ownership concentration (INST CONC). Passive ownership is defined as the fraction of the firm held by funds classifying themselves as index funds, as reported to the SEC on the N-SAR form (see Evans, Ferreira and Prado (2013)). These funds comprise passive investors that track a benchmark index and have long-term horizons that can earn additional income by lending their stock holdings. D'Avolio (2002) describes how "it is the passive indexers who participate most extensively in their custodian's lending program". Evans, Ferreira and Prado (2013) report that most index funds in their sample can and do lend their shares, while Prado, Saffi and Sturgess (2014) show that index fund ownership explains SUPPLY over and above total institutional ownership. Given their passive strategies, it is unlikely that passive funds are concerned with short-term fluctuations in stock prices and consequently, the demand for shorting $(O N L O A N)$, making it a suitable instrument. Stock holdings of these funds are obtained from Morningstar's holdings data and aggregated for each firm on a given quarter.

The second instrument we employ is ownership concentration (INST CONC), measured using the Hirschman-Herfindahl index. Prado, Saffi and Sturgess (2014) show that institutional ownership concentration is an important determinant of SUPPLY even after controlling for total ownership. A more concentrated ownership will result in larger shareholders having more power 
and more interest in impacting lendable supply. If short sale constraints lead to overpricing as in Miller (1977), shareholders can try to limit supply to support prices of their own shares. Hence, more concentrated owners may prefer not to lend stock. Kolasinski, Reed, and Ringgenberg (2013) argue that short sales strategies have short horizons. Thus if concentrated ownership is long-term in terms of investment horizon, it should not be affected by demand for loans in the short term, making it a candidate instrument for SUPPLY.

\section{Empirical Results}

\section{A. Securities Lending Market and Fee}

We first examine the patterns in lendable supply and borrowing demand conditioning on borrowing fee. The evidence in Table 2 illustrates potential issues from ignoring endogeneity and focusing on change in fee alone in estimating the value of the vote. We split the sample of firms into those that are cheap to borrow versus those that "On Special" (i.e., those with borrowing fee greater than $100 \mathrm{bps}$ at $\mathrm{t}=-30$ ). We also show statistics for companies that are extremely expensive to borrow and have fees above $1,000 \mathrm{bps}$ at $\mathrm{t}=-30$. Of the 7,415 record dates only 79 are associated with firms that have borrowing fees above 1,000 bps. Panel A of Table 2 reports averages of equity lending variables at $t=-30$. The average lendable supply as percentage of market capitalization is $14.52 \%$ for firms On Special relative to $25.02 \%$ for firms that are not. Borrowing demand is also higher for the On Special group. The lower supply and higher demand results in a much higher annualized fee of 429 bps for the On Special group, compared with a fee of 9.30 bps for the other group. If investors incorporate the cost of borrowing into the decision to lend or borrow then we expect different record date behavior between the high fee and low fee groups.

Panel B of Table 2 reports the change in lendable supply and borrowing demand on the record date compared with the average for the $(-30,+30)$ window excluding the record date. The 
lendable supply of the On Special group changes by less when compared with the non-special firms both in absolute terms and percentage terms. This implies that lenders recall/restrict more shares when fee is low partly because the potential loss of lending revenue is low. Borrowing demand increases for the non-special firms but actually decreases on the record date for the $O n$ Special group. These descriptive statistics illustrate not only that borrowing fee plays a role in the decision to lend/borrow, but also that the change in fee around the record date is not a sufficient proxy for the value of the vote. Even for On Special firms, the change in fee is small simply because of the slack in supply that is typical in the market for equity lending (UTILIZATION is near 50\% even for FEE>1000 bps split). Combined, these descriptive statistics and the slack in supply provide an important explanation for the low value of the vote based on average fee (e.g., as reported by Christoffersen, Géczy, Musto, and Reed (2007)). Additionally, the fact that fee changes around the record date in response to changes in lendable supply and borrowing demand means that one should incorporate borrowing fee in an analysis of equity lending to capture the endogenous relationship between quantities and prices.

[Table 2 around here]

\section{B. OLS Estimations and Falsification Tests}

Having made an a priori case for our instruments, we also conduct formal empirical falsification tests of their validity. We examine if our prospective instruments affect $F E E$ but are unrelated to SUPPLY (in the case of equations (1) and (2)) or ONLOAN (in the case of equations (3) and (4)). If this is the case, we infer that our instruments meet the exclusion restriction. To conduct our falsification tests we estimate OLS specifications for lendable supply and borrowing demand based on equations (2) and (4), and also for FEE, ignoring endogeneity concerns. We 
include firm and year fixed effects, and cluster the standard errors at the year-level to ensure robustness to heteroskedasticity as well as serial and cross-sectional correlation. In addition to offering evidence on the validity of our instruments, this exercise also offers a glimpse into the record date activity in the equity lending market and further illustrates endogeneity concerns.

For each of the 7,415 record dates, we consider an event window of -30 days to +30 days, where $\mathrm{t}=0$ is the proxy voting record date. We include a record date dummy (RDATE) to examine whether there is abnormal equity lending market activity on the record date compared to the 30 days before and after the record date. We follow Prado, Saffi and Sturgess (2014) by including the following variables to explain securities lending. To control for ownership, we use INST, institutional ownership at the end of the previous quarter measured as a percentage of market capitalization. We use the previous quarter's values of log of market capitalization (SIZE), bookto-market ratio $(B M)$, turnover (TURNOVER), and bid-ask spread (SPREAD) as explanatory variables to control for firm characteristics. We include a dummy for firms with a share price below five dollars $(P R I C E<\$ 5)$. Similar to Kolasinski, Reed and Ringgenberg (2013), we also include short-term momentum (Short-Term Mom) measured as the cumulative return over the five previous days and long-term momentum (Long-Term Mom) as the cumulative return over the previous 252 trading days.

In Table 4 we present the OLS estimations for SUPPLY, ONLOAN, and FEE. In column 1 of Table 4, we test our candidate instruments for ONLOAN, (i.e., Hedging Demand, SUE, and ACCRUALS) by examining their effect on SUPPLY. As expected, all three potential instruments are unrelated to SUPPLY. Further, the results for ONLOAN in column 3 show that Hedging Demand and SUE are negatively related to ONLOAN, and ACCRUALS is positively related to ONLOAN. However, examining the results in column 5 we find that while changes in Hedging 
Demand and SUE affect FEE through ONLOAN, ACCRUALS do not affect FEE. Accordingly, we only adopt Hedging Demand and SUE as instruments for ONLOAN.

[Table 4 around here]

Switching attention to our instruments for SUPPLY, if candidate instruments meet the exclusion restriction then we should expect them to explain SUPPLY but have no explanatory power in the estimation of ONLOAN. Examining the coefficients for PASSIVE and INST CONC in columns 1 and 3 we find this to be the case. Further, both changes in PASSIVE and INST CONC explain changes in fee through SUPPLY. Altogether, the results of the falsification tests support our choice of instruments for both the SUPPLY and ONLOAN equations.

The OLS estimations in Table 4 also present evidence of changes on the record date. The results in columns 1, 3 and 5, show respectively that SUPPLY decreases, ONLOAN increases, and FEE increases on the record date (measured by the RDATE coefficient). As a percentage of market capitalization, the change in lendable supply of $-1.64 \%$ is approximately twenty times larger in magnitude than the increase in $O N L O A N$ of $0.08 \%$. In terms of economic significance, the record date impact on SUPPLY indicates that on average, lendable supply is approximately $7 \%$ lower on the record date compared with the mean over the $[-30,+30]$ sample window. These findings suggest that investors value their vote and therefore recall shares in order to exercise their vote. For ONLOAN, the record date increase is around $2 \%$ of the mean over the $[-30,+30]$ sample window. ${ }^{17}$

Further examination of results for lendable supply, reveal that it is higher when institutional ownership (INST) is higher, when institutional ownership is dispersed (INST CONC), for larger firms (SIZE), and value firms (BM). Turning to columns 3 and 4, borrowing demand is higher if institutional ownership is higher, and for firms that are more liquid. Unsurprisingly, there is a negative and significant association between prior performance and borrowing demand. In 
addition to standard control variables, we include firm-level corporate governance, GOV41. Firms with better governance have higher lendable supply and lower borrowing demand. These results are consistent with better governance alleviating shareholders' concerns that share lending will be detrimental to the value of their holdings, possibly because good governance deters short-selling.

Column 5 of Table 4 reports the results for FEE. The coefficient of RDATE is positive and significant at $1 \%$, implying that the fee for borrowing stock increases on the record date. This corresponds to a $3.68 \%$ increase relative to mean over the $[-30,+30]$ sample window, suggesting that the market values voting. However, the coefficient of 1.776 implies that the value of the vote, if measured as the change in fee, is economically small.

In columns 2 and 4 we also include FEE directly in the OLS estimations of SUPPLY and ONLOAN respectively. In the absence of endogeneity concerns one should expect SUPPLY $(O N L O A N)$ to be increasing (decreasing) in FEE. However, the estimated coefficients are precisely the opposite of this, reflecting instead the endogenous relationship between FEE and quantity. This result reinforces our endogeneity concerns highlighted in Section 5.1. The borrowing fee itself changes around the record date in response to changes in supply and demand, and therefore one should not only incorporate borrowing fee in an analysis of equity lending quantities but also address the endogenous relationship between quantity and prices.

\section{Securities Lending around Proxy Record Dates}

Focusing on lendable supply, our empirical strategy estimates SUPPLY as a function of the simultaneously determined price (FEE), a record date dummy (RDATE), and the interaction of price and the record date dummy $\left(R D A T E^{*} F E E\right)$, as in specification (2). In the first stage, we employ instruments for $O N L O A N$ to estimate exogenous shifts in FEE. The previous estimated equation shown in column 5 of Table 4 gives the first stage estimates for FEE. 
Table 5 displays our main second-stage results for equations (2) and (4) using the instrumented fee from the first stage. All equations include the firm characteristics described above as control variables, firm and year fixed effects, and standard errors clustered by firm. Columns 1 and 2 show estimates for SUPPLY with and without the RDATE*FEE coefficient. In column 1, the record date effect equals $-1.625 \%$, close to the effect presented in Table 4 . This recall in lendable supply indicates that lenders of shares recall their shares because they value their vote. Further, we find that, in general, SUPPLY is insensitive to fee within firm, consistent with a flat supply curve. This is in stark contrast to the negative association documented in OLS estimates in Table 4. In column 2, we include the interaction term RDATE*FEE. The coefficient on $R D A T E^{*} F E E$ is positive and statistically significant at the $10 \%$ level, implying that the recall of shares at the record date is sensitive to borrowing fee and that recall is lower if the fee received by lenders is higher. The Kleibergen-Paap statistic tests if the instruments are sufficiently correlated with the included endogenous regressors. We can safely reject the null that endogenous variables are under-identified and obtain similar conclusions using the Cragg-Donald Wald statistic. Because there are two or more instruments for lending supply and borrowing demand we also perform the J-test of over-identifying restrictions under the assumption that at least one instrument is exogenous. Results show that we cannot reject the null hypothesis that our instruments are exogenous.

[Table 5 around here]

Next, we turn our attention to those participants that borrow stock around the record date. Columns 3 and 4 report results for specification (4) using ONLOAN as the dependent variable. The positive and statistically significant RDATE coefficients indicate an increase in borrowing demand on the record date. However, borrowing demand is lower for firms with a higher borrowing fee. 
The statistically significant coefficient for $R D A T E^{*} F E E$ implies that, for very expensive firms, demand may actually decreases on the record date, in line with the descriptive statistics shown for ON SPECIAL firms in Table 2.

Overall, the estimated change in lendable supply on the record date is much larger than the change in borrowing demand. These results support the hypothesis that lenders, such as pension funds and mutual funds, weigh their vote and the potential lending income before restricting lendable supply. The decrease in lendable supply means that investors assign a higher value to voting than the potential income they could earn from lending.

\section{Heterogeneity in Preferences of Institutional Investors}

Institutional investors differ along several dimensions that affect their willingness to exert governance through voting (e.g., Matvos and Ostrovsky (2010) and Duan and Jiao (2014)). Heterogeneity in voting preferences will depend on several factors including their overall investment philosophy, investment horizon, fiduciary responsibility, ability or incentives to engage with management and/or invest in private information required for effective monitoring. These differences in ownership compositions are likely to be reflected in the equity lending market activity on the record date. For example, institutions with larger economic stakes, such as blockholders, should be able to better overcome the free-rider problem highlighted by Shleifer and Vishny (1986) and thus have the incentive to both monitor and govern through voting. Therefore, we focus on blockholdings when examining the preferences of institutional investors.

Table 6 presents results on heterogeneity of institutional preferences by examining alternative ownership structures. We examine the composition of institutional ownership, rather than the composition of institutional lending, because the securities lending data does not provide the identity of the lender and borrower. Consequently, our empirical analysis on investor 
heterogeneity relies on differences in ownership at the firm-level, rather than heterogeneity at the lending level. We repeat the IV estimations presented in Table 5 but replace the RDATE dummy with RDATE*HIGH and RDATE*LOW. The HIGH (LOW) dummy variable indicates the ownership composition in question. Using total blockholdings as an example, $H I G H(L O W)$ takes the value of one if institutional blockholding is above (below) the median. This setup allows us to examine the change in lendable supply and borrowing demand based on different types of institutional investors. We examine total institutional ownership, aggregate blockholdings, and those blocks belonging to four types of investors: mutual funds, banks and insurance companies, pension funds, and endowments using the classification in Bushee and Goodman (2007), while we define the proportion of long-term investors based on Chen, Harford and Li (2007).

To provide a benchmark, Panel A of Table 6 reports results based on total institutional ownership. We find no significant difference in the change in $S U P P L Y$ or $O N L O A N$ on record date between firms below and above the median. However, this result changes when we focus on blockholders in Panel B. Large blockholders have more incentives to monitor the firm, which results in greater record date recall. In the lendable supply equation, the coefficient of $R D A T E^{*} H I G H$ is -2.915 while the coefficient of $R D A T E^{*} L O W$ is -1.688 , and the difference is statistically significant. The negative and significant coefficients imply that both high and low blockholders recall shares, but we find the recall to be greater for firms with greater blockholdings. In panels $\mathrm{C}, \mathrm{D}$ and $\mathrm{E}$, we report results using blockholdings held by mutual funds, banks and insurance companies, and pension funds and endowments, respectively. These types of institutional investors have more fiduciary responsibilities than other types of institutions. Both mutual funds and the pension funds and endowments groups are active participants in the securities lending market. Again, we find that larger holdings by these groups of institutions results in higher 
recall. In Panel F, we show that long-term investors, who are more likely to be interested in corporate governance and have incentives to engage with management, recall more of their shares on the record date. The results are similar if the high/low categories are based on total ownership rather than blockholdings.

[Table 6 around here]

In each case, we repeat the analysis for borrowing demand and find that the demand to borrow shares increases for each type of investor, however, the difference between high and low ownership type is not significant.

\section{E. Heterogeneity in Firm and Proposal Characteristics}

The benefits of shareholder intervention may vary not only with their individual stake but also with the value originating from such intervention. Consequently, recall should also be a function of both firm and proposal characteristics. In Table 7, we examine changes in lendable supply and borrowing demand on the record date based on several firm characteristics: corporate governance, stock returns during the past 12-months, and market capitalization. For each of these characteristics, we expect the interest in voting to vary. For example, the value of the vote is likely to be greater for firms with weak governance when compared to firms with strong governance. Within firm, there may be time-series variation in voting rights. For example, in periods of low returns investors may place a higher value on implementing change through voting. Finally, the value of the vote might vary with size because the vote may hold more influence in smaller firms where ownership is less dispersed. Panel A of Table 7 splits firms into low and high corporate governance based on GOV41. Institutional investors prefer not to lend out shares on the record date for firms with weak governance. The interaction of $R D A T E^{*} L O W$ based on firm-level corporate governance is -2.446 and for $R D A T E^{*} H I G H$ the coefficient is 
-1.727. Both coefficients and the difference are statistically significant. Again, the results suggest that on average, the recall of lendable supply occurs for all firms, and is higher for firms with weak governance. In the case of firms with weaker governance, institutional investors are even more interested in recalling their shares and voting with their voice.

[Table 7 around here]

In Panel B, we present splits by low and high monthly returns in the preceding twelve months. Share lenders are particularly interested in exercising their vote in firms that are not performing well, where they can use the vote to bring about change at the firm. We find that the recall is larger for firms that have performed below the median. In Panel C, the sample is split based on market capitalization and we find that recall is significantly higher in smaller firms. These firms likely face bigger information asymmetry problems and we would expect that lenders would have more incentives to exercise their opinions through voting. In all panels, the difference between low and high groups is not significant for borrowing demand.

In Panels $\mathrm{D}$ to $\mathrm{G}$ we also examine changes in lendable supply and borrowing demand around record dates associated with proxy events that are deemed to be more "important" to shareholders. We report results using four alternative splits based on the presence of at least one of the following types of proposals: non-routine, compensation-related, anti-takeover, and corporate control (proxy contests and mergers). We split the sample based on whether the record date is associated with a proxy event or not in the ballot. However, we omit firms from both subsamples that do not have at least one proxy event in question.

In Panel D of Table 7, we show results for record dates with and without non-routine proposals. Non-routine proxy proposals include proposals relating to anti-takeover provisions, 
stock capitalization and mergers. For SUPPLY, we find higher recall when at least one non-routine proposal is present in the ballot but find no statistical difference for ONLOAN.

Panel E splits the sample according to the presence of at least one compensation-related proposal and yields similar results. With the increased prominence of corporate governance concerns, managerial compensation policies have become a focus of investors' attention and we expect it to be reflected into a higher value of the vote. The importance of compensation related proxy proposals is revealed in the results. The estimated SUPPLY change on record dates with compensation related proposals, -2.608 , is $16 \%$ more negative than on record dates with those proposals. Again, we find no significant difference on the demand side.

The third group of contentious proposals we consider in Panel F is based on anti-takeover provisions (G-INDEX) included in the G-Index developed by Gompers, Ishi, and Metrick (2003). We find that record dates with G-INDEX related proposals have higher recalls than non-G-INDEX related proposals and the difference is statistically significant.

Finally, in Panel G of Table 7, we consider record dates with proposals related to corporate control by examining proxy contests and mergers. In a proxy contest, shareholders vote to resolve a conflict between the firm's management and board of directors, referred to as "incumbents", and a group of shareholders, referred to as "dissidents". Some examples of high profile proxy contests include Carl Icahn's efforts to unseat Yahoo's board in 2008, and Hewlett Packard - Compaq merger in 2001. Dissident shareholders can initiate the proxy contest by filing a preliminary proxy statement PREC14A and definitive proxy statement in connection with contested solicitations DEFC14A. Data on proxy contests are hand-collected and supplemented with data from Sharkrepellent.net, an organization that covers proxy fights and activism; for mergers we identify proposals for targets and acquirers in the ISS database. The change in SUPPLY on record dates 
with corporate control related proposals is almost $40 \%$ larger than those without those types of proposals. For borrowers, the difference in demand between corporate control and non-corporate control related proposals is not statistically significant.

In summary, we show that the value of the vote varies based on type of investor, firm characteristics, and proposal types on the lendable supply side. These results provide evidence that institutional investors monitor firms and selectively recall shares to vote, and rule out that institutional investors recall their shares mechanically for window dressing purposes.

\section{F. Estimating the Value of the Vote for Institutional Investors}

The results on recall of lendable supply around the record date illustrate that while some institutions recall shares to exert governance through voting, other institutions continue to lend shares. This has significant implication for estimating the value of the vote using the equity lending market: so long as some institutions continue to provide enough shares to meet the demand, the recall in supply or an increase in demand may have little impact on borrowing fee. As shown by Kolasinski, Reed, and Ringgenberg (2013), and Prado, Saffi and Sturgess (2014) this slack supply situation is the norm in this market.

In an attempt to provide a meaningful estimate for the value of a vote, we examine the change in the borrowing fee on the record date that would offer lenders sufficient compensation to continue lending at the same levels observed in non-record date days rather than recall shares. ${ }^{18}$ Methodologically, in terms of equation (2) this is equivalent to setting the combined record date effect on estimated quantities to zero and solving for fee given the estimated parameters. Therefore, we solve $\gamma^{S}+\beta_{2}^{S} F e e=0$, such that the value of the vote, VVOTE, is defined as:

VVOTE $E_{\text {Supply }}=-\frac{\gamma^{s}}{\beta_{2}^{S}}$ 
Since VVOTE is determined as a function of estimated coefficients, representing the average shift in quantity and price-elasticity across record dates, it is equivalent to the fee required to ensure zero recall, relative to non-record date days, for the average stock. Consequently, one might interpret VVOTE as the value of the vote for the institution with the highest valuation rather than the marginal institution. The non-linear combination of parameters required to estimate VVOTE leads us to use the delta method to compute standard errors and test for statistical significance. The estimate for VVOTE $E_{\text {Supply }}$ is equal to $267.8 \mathrm{bps}$ in annualized terms (1.06 bps per day) with an estimated standard error equal to $119 \mathrm{bps}$, being significant at the $1 \%$ value. We find that lenders assign almost twice as much value to votes than borrowers on the record date. The fact that investors start to recall their shares around twenty days (Figure 1) before the record date affects the economic interpretation of the value of the vote. This implies that lenders are willing to give up $((20 / 252) * 267.8 / 100=) 0.2 \%$ of the value of shares available to borrow to vote.

While our focus is on institutional investors, we can also estimate VVOTE for those investors that demand shares around the record date. VVOTE $E_{\text {Demand }}$ is equal to $111.4 \mathrm{bps}$ in annualized terms ( $0.44 \mathrm{bps}$ per day) and has a standard error equal to $17 \mathrm{bps}$, also significant at the $1 \%$ level.

The fact that institutions spend time and resources to set up policy, monitor, and selectively recall reflects that they care about their vote. ${ }^{19}$ This is another reason for why the value of the vote may not be fully captured by the fee and our estimates are likely a lower bound since they do not fully capture these unobservable costs.

\section{Voting Outcome}

To understand how institutional voting shapes proxy outcomes, in this section we examine whether the recall of supply by institutional investors has any impact on the vote outcome at the 
shareholder meeting. We estimate regressions for the 6,887 non-routine proposals where the dependent variable is FOR, the percentage of votes in favor of a proposal. ${ }^{20}$ For each proposal we test if the restriction in lendable supply and the increase in demand around the record date play a role on how votes are cast on the subsequent meeting date. Importantly, the meeting date is on average 53 days after the record date. If institutions recall lendable supply to exercise their vote, then we should expect that voting outcome is associated with recalled supply.

The independent equity lending variables are the change in lendable supply, $\triangle S U P P L Y$, and the change in borrowing demand, $\triangle O N L O A N$. These changes are based on the average lendable supply and on loan during days $(\mathrm{t}=-30$ to -20$)$ to the record date $(\mathrm{t}=0)$. We include indicator variables for management proposals that management supports and the proxy advisory service ISS opposes (DISS), for shareholder-sponsored proposals (DSHR), and for proposals relating to compensation $(C O M P)$, G-INDEX $(G-I N D E X)$, and corporate control (CORP CONTROL) that we examined in Section 5. We also interact the change in supply and the change in on loan with these characteristics to better understand when equity lending activity is important to determine support for a proposal. Further, we include the firm-specific characteristics and proposal fixed effects included in the earlier estimations, but omit these for brevity in Table 8. All regressions include firm fixed effects, time dummies, and standard errors are double clustered at the firm and year levels.

In column 1 of Table 8 , we present evidence that shows the record date change in lendable supply is positively associated with more votes against the proposal. The coefficient of $\triangle S U P P L Y$ of 0.350 implies that a recall in lendable supply (i.e., a decrease in $\triangle S U P P L Y$ ) is negatively associated with support for non-routine proposals; however, significance is only at the $10 \%$ level. We find no relation between borrowing demand and a larger proportion of FOR votes for 
proposals. Further, shareholder sponsored proposals exhibit $44 \%$ less FOR votes, on average, than management sponsored proposals for the same firm. However, the significant coefficient of -2.444 on $\triangle S U P P L Y * D S H R$ shows that the record date recall in supply is positively associated with more votes being cast in favor of shareholder sponsored proposals.

Next, in column 2, we introduce proposal characteristics and advice from proxy advisory services. Consistent with Alexander et al (2010), we find that the recommendations of proxy advisors play an important role in the outcome of proposals. In general proposals that ISS recommends against management are associated with significantly lower support. Further, the significant coefficient of 1.545 on $\triangle S U P P L Y * D I S S$ implies that a higher recall (negative $\triangle S U P P L Y$ ) at the record date leads to fewer votes being cast in favor of a proposal if ISS opposes management. This is consistent with institutional investors responsibly fulfilling a monitoring role whereby they provide prudence on behalf of shareholders. Switching focus to proposal characteristics we find greater support for compensation, G-Index, and corporate control proposals. However, where the recall of lendable supply is higher the support for these proposals is lower: the coefficients estimated by interacting $\triangle S U P P L Y$ with these three proposal types are all positive and significant. In Section 5 we show that institutional investors placed a higher value on voting rights for these types of proposals; here we show that when institutions do recall shares they tend to vote against the proposal. This finding is consistent with institutional investors providing monitoring of managerial activities via the proxy process. We also find evidence that higher borrowing is associated with less support for proposals that ISS recommends against but not much for compensation, G-Index, and corporate control.

[Table 8 around here] 
The results in columns 1 and 2 of Table 8 show indirect evidence that a recall in lendable supply is positively associated with votes for shareholder proposals, and against management proposals related to compensation, governance and corporate control. An alternative explanation is that institutions recall shares to vote with management when support for management is low. Because we do not know the identity of the institutions that recall shares, we try to rule out this alternative explanation by examining the voting behavior of mutual funds, who are one of the largest lenders of shares.

We obtain data on mutual fund voting behavior reported on SEC Form N-PX. Form N-PX identifies all proposals on which the fund has voted portfolio securities and discloses how the fund voted on each proposal (the number of shares voted is not required to be disclosed). Our sample includes mutual fund voting data for 6,651 individual funds that are part of 308 institutions (mutual fund families) for the 3,826 record dates that include non-routine proposals. In total we have 1,524,290 fund-proposal voting behavior in our sample. In column 3 of Table 8, we examine how voting outcome is affected by recall in supply for mutual funds by estimating if the mutual fund voted FOR the proposal, where FOR is equal to 100 if the fund voted in favor of the proposal, and zero otherwise. ${ }^{21} \mathrm{We}$ repeat the estimation of FOR presented in column 2 but at the mutual fund level, and include fund family fixed effects in addition to firm fixed effects to control for fund family-level policies on both voting and lendable supply recall. The results show that mutual fund voting is associated with support for proposals where there is a greater recall in general. However, where ISS recommends against the proposal or the proposal is related to compensation or antitakeover provisions a larger recall in supply is associated with less support from mutual funds. This result alleviates the concern that mutual funds are recalling shares to vote with management when other shareholders are following ISS's advice and voting against management. 
Collectively, these results show that institutional investors that choose to retain voting rights have a meaningful impact on voting outcomes. While the fewer number of votes in favor of proposals may not result in the proposal being rejected, there is evidence that votes recorded against proposals have spillover governance effects. Cai, Garner, and Walkling (2009) and Fischer et al. (2009) show that meaningful vote totals against director election proposals, even where the proposal passes, are followed by changes in the board, management, or corporate actions within the next year.

\section{Conclusion}

The preferences of institutional investors tend to be private and usually cannot be studied because they are often conducted behind the scenes. We use the unique setting of the equity lending market to observe the role of institutional investors in corporate governance. Lending fee is an important source of revenue for many institutional investors and enhances their performance. For example, in 2012, Vanguard reported that securities lending increased annual fund returns by more than 1 basis point for over $60 \%$ of its funds, by more than 5 basis points for nearly a third of funds, and by more than 10 basis points for over $15 \%$ of funds. ${ }^{22}$ However, if institutions have loaned out their shares on the record date, then they cannot exercise their vote. Hence, institutional investors must decide whether to restrict lending and even recall shares already on loan in the event of an upcoming vote. Just prior to the proxy record date, we find a significant reduction in lendable supply, because institutions restrict or call back their loaned shares in order to vote.

We find heterogeneity in the recall to vote based on institutional investor composition, firm and proposal characteristics. These results show that recall is higher for firms with a higher proportion of investors with stronger incentives to monitor and exert governance, for stocks where governance is more valuable and for proposals where the returns to governance are likely higher. 
Finally, to understand how institutional voting shapes proxy outcomes, we examine the subsequent vote outcome and find higher recall to be associated with less support for management proposals such as those relating to compensation and corporate control, and more support for shareholder proposals. Thus our results are consistent with shareholder voting acting as an effective governance mechanism, but only when the economic stake is large enough or economic benefit great enough to overcome the free-rider problem that arises from the dispersed ownership.

Overall, our findings imply that institutional investors value their vote and use the proxy voting process as an important channel for affecting corporate governance. Our analysis suggests policy makers should address several issues related to proxy voting, including the need for investors to learn about proxy items before the record date so that they can decide whether to lend their shares or not. 


\section{References}

Aggarwal, Reena, Isil Erel, Miguel Ferreira, and Pedro Matos, 2011, Does governance travel around the world? Evidence from Institutional Investors, Journal of Financial Economics, $100,154-182$.

Alexander, Cindy, Mark Chen, Duane Seppi, and Chester Spatt, 2010, Interim news and the role of proxy voting advice, Review of Financial Studies, 23, 4419-4454.

Angrist, Joshua D., Kathryn Graddy, and Guido W. Imbens, 2000, The interpretation of instrumental variables estimators in simultaneous equations models with an application to the demand for fish, Review of Economic Studies, 67, 499-527.

Angrist, Joshua D., and Jörn-Steffen Pischke, 2009, Mostly Harmless Econometrics (Princeton Press, Princeton, NJ).

Becker, Gary S. and Julio Jorge Elias, 2007, Introducing incentives in the market for live and cadaveric organ donations, Journal of Economic Perspectives, 21, 3-24.

Blau, Francine D. and Lawrence M. Kahn, 2007, Changes in the labor supply behavior of married women: 1980-2000, Journal of Labor Economics, 25, 393-438.

Blundell, Richard, Alan Duncan and Costas Meghir, 1998, Estimating labor supply responses using tax reforms, Econometrica, 66(4), pages 827-862.

Blundell, Richard and Thomas E. Macurdy, 1991, Labor supply: A review of alternative approaches, in: O. Ashenfelter \& D. Card (ed.), Handbook of Labor Economics, edition 1, volume 3, chapter 27, 1559-1695.

Blocher, Jesse, Adam V. Reed, and Edward D. Van Wesep, 2013, Connecting two markets: an equilibrium framework for shorts, longs and stock loans, Journal of Financial Economics, $108,302-322$. 
Brav, Alon, Wei Jiang, Frank Partnoy, and Randall Thomas, 2008, Hedge fund activism, corporate governance, and firm performance, Journal of Finance, 63, 1729-1775.

Brickley, James A., Ronald C. Lease, and Clifford W.Smith, 1988, Ownership structure and voting on antitakeover amendments, Journal of Financial Economics, 20, 267-291.

Bushee, Brian J., 1998, The influence of institutional investors on myopic R\&D investment behavior, Accounting Review, 73, 305-353.

Bushee, Brian J., 2001, Do institutional investors prefer near-term earnings over long-run value? Contemporary Accounting Research, 18, 207-246.

Bushee, Brian J., Mary Ellen Carter, and Joseph Gerakos, 2013, Institutional investor preferences for corporate governance mechanisms, Journal of Management Accounting Research, forthcoming.

Bushee, Brian J., and Theodore H. Goodman, 2007, Which institutional investors trade based on private information about earnings and returns, Journal of Accounting Research, 45(2), 289321.

Cai, Jie, Jacqueline L. Garner, and Ralph A. Walkling, 2009, Electing directors, Journal of Finance, 64, 2389-2421.

Chen, Xia, Jarrad Harford, and Kai Li, 2007, Monitoring: Which institutions matter, Journal of Financial Economics, 86, 279-305.

Christoffersen, Susan Kerr, Christopher Géczy, David K. Musto, and Adam V. Reed, 2007, Vote trading and information aggregation, Journal of Finance, 62, 2897-2929.

Christophe, Stephen E., Michael G. Ferri, and James J. Angel, 2004, Short-selling prior to earnings announcements, Journal of Finance, 59, 1845-1876. 
Clifford, Christopher P., 2008, Value creation or destruction: Hedge funds as shareholder activists, Journal of Corporate Finance, 14, 323-336.

Cuñat, Vincente, Mireia Gine, and Maria Guadalupe, 2012, The vote is cast: The effect of corporate governance on shareholder value, Journal of Finance, 67, 1943-1977.

D'Avolio, Gene, 2002, The market for borrowing firm, Journal of Finance Economics, 66, 271306.

Duan, Ying and Yawen Jiao, 2014, The role of mutual funds in corporate governance: Evidence from mutual funds' proxy voting and trading behavior, Journal of Financial and Quantitative Analysis, Forthcoming.

Edmans, Alex, 2009, Blockholder trading, market efficiency, and managerial myopia, Journal of Finance, 64, 2481-2513.

Edmans, Alex, 2014, Blockholders and corporate governance, Annual Review of Financial Economics, forthcoming.

Eissa, Nada and Jeffrey B. Liebman, 1996. Labor supply response to the earned income tax credit, The Quarterly Journal of Economics, 111, 605-637.

Eissa, Nada and Hilary W. Hoynes, 2004, Taxes and the labor market participation of married couples: The earned income tax credit, Journal of Public Economics, 88, 1931-1958.

Evans, Richard B., Miguel A. Ferreira, and Melissa P. Prado, 2013, Equity lending, investment restrictions and fund performance, Working Paper, University of Virginia.

Fischer, Paul E., Jeffrey D. Gramlich, Brian P. Miller, and Hal D. White, 2009, Investor perceptions of board performance: evidence from uncontested director elections, Journal of Accounting and Economics, 48, 172-189. 
Fos, Vyacheslav, 2011, The disciplinary effects of proxy contests, Working Paper, University of Illinois at Urbana-Champaign.

Gantchev, Nickolay, 2013, The costs of shareholder activism: Evidence from a sequential decision model, Journal of Financial Economics, 107, 610-631.

Gaspar, Jose-Miguel, Massimo Massa and Pedro P. Matos, 2005, Shareholder investment horizons and the market for corporate control, Journal of Financial Economics, 76, 135-165.

Gillan, Stuart L., and Laura T. Starks, 2000, Corporate governance proposals and shareholder activism: The role of institutional investors, Journal of Financial Economics, 57, 275-305.

Gompers, Paul, Joy Ishii and Andrew Metrick, 2003, Corporate governance and equity prices, Quarterly Journal of Economics, 118(1), 107-155.

Grene, Sophia, September 12, 2010, Guide issued on securities lending, FT.Com, http://www.ft.com/cms/s/0/5da3c26c-bd04-11df-954b-00144feab49a,dwp_uuid=571fa9eab6a7-11db-8bc2-0000779e2340.html.

Hall, Robert E. and Charles I. Jones, 2007, The value of life and the rise in health spending, The Quarterly Journal of Economics, 122, 39-72.

Hanemann, W. Michael, 1994, Valuing the environment through contingent valuation, Journal of Economic Perspectives, 8, 19-43.

Hartzell, Jay C., and Laura T. Starks, 2003, Institutional investors and executive compensation, Journal of Finance, 58, 2351-2374.

Helwege, Jean, Vincent J. Intintoli, and Andrew Zhang, 2012, Voting with their feet or activism? Institutional investors' impact on CEO turnover, forthcoming, Journal of Corporate Finance. Hu, Henry T.C., and Bernard S. Black, 2006, The new vote buying: empty voting and hidden ownership, Southern California Law Review, 79, 811-908. 
Hu, Henry T.C., and Bernard S. Black, 2008, Equity and debt decoupling and empty voting ii: Importance and extensions, University of Pennsylvania Law Review, 156, 625-739.

Hwang, Byoung-Hyoun, Baixiao Liu, and Wei Xu, 2013, Can short selling help correct underpricing? Working Paper, Purdue University.

Iliev, Peter, and Michelle Lowry, 2013, Are mutual funds active voters? Working Paper, Pennsylvania State University.

Kahn, Charles, and Andrew Winton, 1998, Ownership structure, speculation, and shareholder intervention, Journal of Finance, 53, 99-129.

Kalay, Avner, Oguzhan Karakas, and Shagun Pant, 2014, The market value of corporate votes: Theory and evidence from option prices, Journal of Finance, 69, 1235-1271.

Ke, Bin, Santhosh Ramalingegowda, 2005, Do institutional investors exploit the post-earnings announcement drift? Journal of Accounting and Economics, 39, pages 25-53.

Klein, April, and Emanuel Zur, 2009, Entrepreneurial shareholder activism: Hedge funds and other private investors, Journal of Finance, 64, 187-229.

Kling, Catherine L., Daniel J. Phaneuf, and Jinhua Zhao, 2012, From Exxon to BP: Has some number become better than no number?, Journal of Economic Perspectives, 26, 3-26.

Kolasinski, Adam C., Bing Cao, Adam V. Reed, and Dan S. Dhaliwal, 2007, Bears and numbers: Investigating how short sellers exploit and affect earnings-based pricing anomalies, Working Paper.

Kolasinski, Adam C., Adam V. Reed, and Matthew Ringgenberg, 2013, A multiple lender approach to understanding supply and demand in the equity lending market, Journal of Finance, 68, 559-595. 
Livnat, Joshua, and Richard R. Mendenhall, 2006, Comparing the post-earnings announcement drift for surprises calculated from analyst and time series forecasts, Journal of Accounting Research, 44, 177-205.

Maug, Ernst, 1998, Large shareholders as monitors: Is there a trade-off between liquidity and control? Journal of Finance, 53, 65-98.

Matvos, Gregor, and Michael Ostrovsky, 2010, Heterogeneity and peer effects in mutual fund proxy voting, Journal of Financial Economics, 98, 90-112.

McCahery, Joseph A., Zacharias Sautner, and Laura T. Starks, 2011, Behind the scenes: the corporate governance preferences of institutional investors, Working Paper, University of Amsterdam.

Meyer, Bruce D. and Dan T. Rosenbaum, 2001, Welfare, the earned income tax credit, and the labor supply of single mothers, The Quarterly Journal of Economics, 116, 1063-1114.

Miller, Edward M., 1977, Risk, uncertainty, and divergence of opinion, Journal of Finance, 32, $1151-1168$.

Miller, Klaus M., Reto Hofstetter, Harley Krohmer, and Z. John Zhang, 2011, How should consumers' willingness to pay be measured? An empirical comparison of state-of-the-art approaches, Journal of Marketing Research, 48.

Moser, Shane S., Bonnie F. Van Ness, and Robert A. Van Ness, 2013, Securities lending around proxies: Is the increase in lending due to proxy abuse, or a result of dividends? Journal of Financial Research, 36, 1-17.

Parrino, Robert, Richard W. Sias, and Laura T. Starks, 2003, Voting with their feet: Institutional ownership changes around forced CEO turnover, Journal of Financial Economics, 68, 3-46. 
Prado, Melissa P., Pedro A. C. Saffi, and Jason Sturgess, 2014, Ownership structure, limits to arbitrage and stock returns: Evidence from equity lending markets, Working Paper, DePaul University.

Rothstein, Jesse, 2010, Is the EITC as good as an NIT? Conditional cash transfers and tax incidence, American Economic Journal: Economic Policy, 2, 177-208.

Saffi, Pedro A. C., and Kari Sigurdsson, 2011, Price efficiency and short selling, Review of Financial Studies, 24, 821-852.

Shleifer, Andrei and Robert W. Vishny, 1986, Large shareholders and corporate control, Journal of Political Economy, 94, 461-88.

Sloan, Richard G., 1996, Do stock prices fully reflect information in accruals and cash flows about future earnings? The Accounting Review, 71, 289-315.

Wooldridge, Jeffrey M., 2001, Econometric Analysis of Cross Section and Panel Data, Edition 1, Volume 1, 231. (MIT Press Books, The MIT Press) 


\section{Figure 1 \\ Equity Lending Market Activity around Record Date}

The figure presents a daily plot of lendable supply, on loan, utilization and loan fees for the period $(-30,+30)$ for 7,415 record dates (day $\mathrm{t}=0$ is the proxy voting record date) during the years 2007-2009. SUPPLY is the percentage of market capitalization available to lend; ONLOAN is the percentage of market capitalization actually borrowed; UTILIZATION is the ratio of ONLOAN to SUPPLY expressed in percentage; FEE is the annualized borrowing fees expressed in basis points. In the top panel, SUPPLY is shown on the left-hand axis and UTILIZATION is shown on the right-hand axis. In the bottom panel, the left-hand axis shows $O N L O A N$ and the right-hand axis shows FEE.

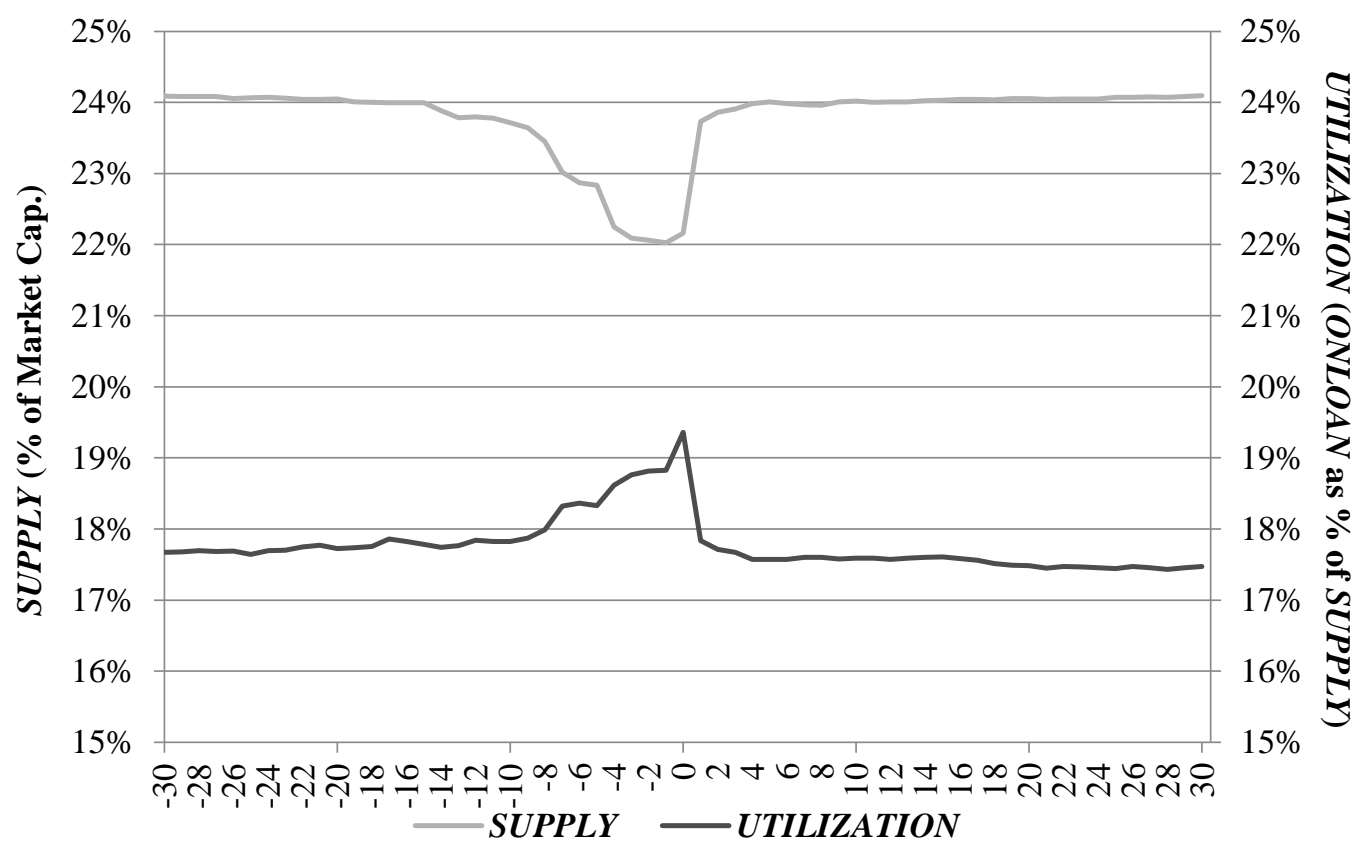




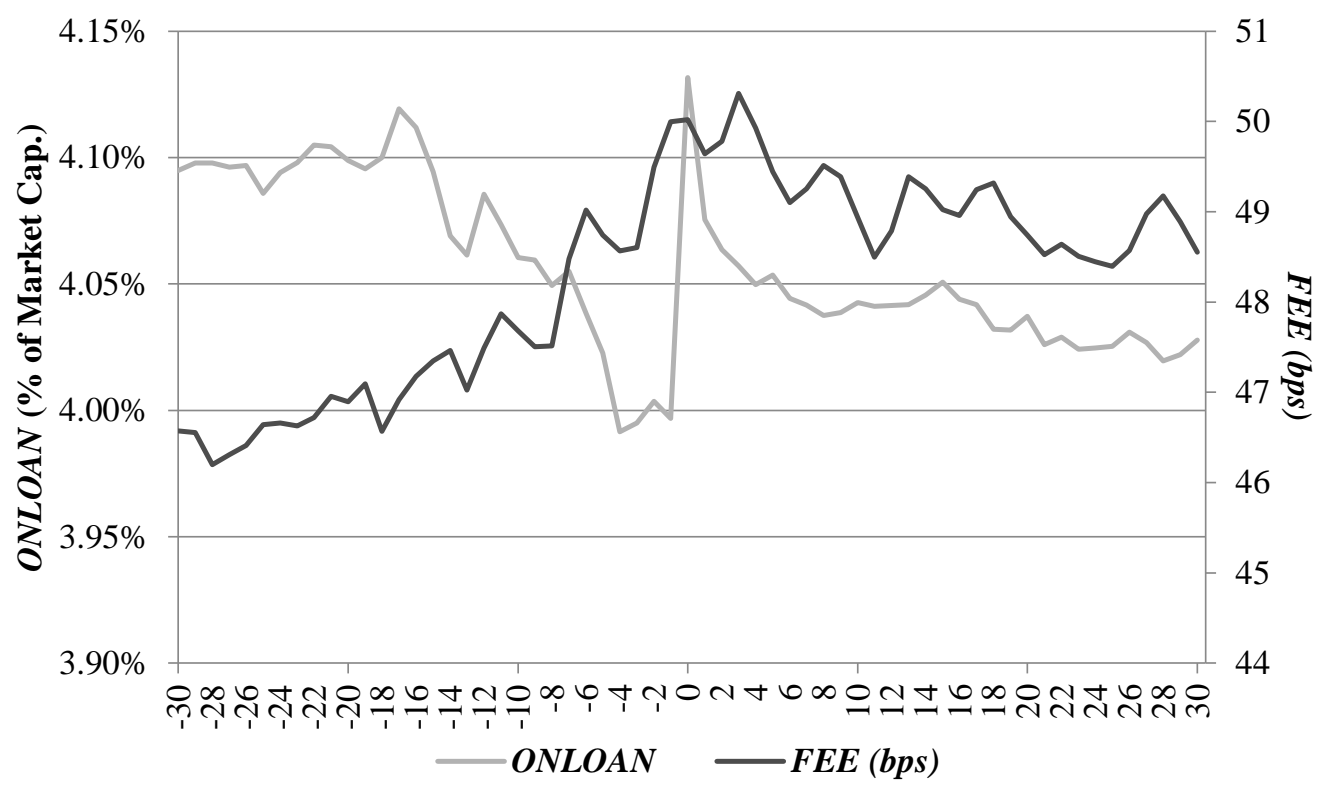


Table 1

\section{Equity Lending Characteristics}

The table presents characteristics of the equity lending market around the record dates of Russell 3000 firms from 2007 to 2009. SUPPLY is the percentage of market capitalization available to lend; ONLOAN measures borrowing demand and is the percentage of market capitalization actually borrowed; FEE is the annualized borrowing fee expressed in basis points; and UTILIZATION is the ratio of ONLOAN to SUPPLY expressed in percentage. SPECIAL includes firms with a borrowing fee in excess of $100 \mathrm{bps}$. SUPPLY, ONLOAN, and FEE are winsorized at $1 \%$.

\begin{tabular}{lcccccc}
\hline \multicolumn{7}{c}{ Equity Lending Characteristics } \\
\hline SUPPLY & Obs. & Mean & Median & Std Dev & Min & Max \\
ONLOAN & 7,415 & $23.78 \%$ & $24.23 \%$ & $10.71 \%$ & $1.65 \%$ & $48.57 \%$ \\
FEE & 7,415 & $4.06 \%$ & $2.63 \%$ & $4.22 \%$ & $0.01 \%$ & $20.49 \%$ \\
UTILIZATION & 7,415 & 48.28 & 9.90 & 158.25 & -50.84 & 1113.81 \\
SPECIAL & 7,415 & $17.78 \%$ & $12.59 \%$ & $16.25 \%$ & $0.23 \%$ & $68.90 \%$ \\
\hline
\end{tabular}


Table 2

Lendable Supply, Borrowing Demand and Fee for Firms “On Special”

Panel A of the table reports the averages of equity lending variables at $\mathrm{t}=-30$ and Panel $\mathrm{B}$ reports the percentage points change in each lending attribute on the record date compared with the average over the $(-30,+30)$ days period (excluding the record date). On Special includes firms with a borrowing fee in excess of $100 \mathrm{bps}$, measured on $\mathrm{t}=-30 . S U P P L Y$ is the percentage of market capitalization available to lend. ONLOAN is the percentage of market capitalization actually borrowed; $F E E$ is the annualized borrowing fees expressed in basis points; and UTILIZATION is the ratio of ONLOAN to SUPPLY expressed as a percentage.

\begin{tabular}{|c|c|c|c|c|c|}
\hline \multicolumn{6}{|c|}{ Panel A: Lendable Supply, Borrowing Demand and Fee at $t=-30$} \\
\hline On Special & \#(Record Dates) & SUPPLY & ONLOAN & FEE & UTILIZATION \\
\hline No & 6,756 & $25.02 \%$ & $3.83 \%$ & 9.30 & $15.20 \%$ \\
\hline Yes & 659 & $14.52 \%$ & $6.85 \%$ & 428.68 & $42.96 \%$ \\
\hline FEE $>1000 \mathrm{bps}$ & 79 & $12.40 \%$ & $6.44 \%$ & 1108.37 & $50.81 \%$ \\
\hline \multicolumn{6}{|c|}{ Panel B: Record Date Change from the Average Level for the Event Window } \\
\hline On Special & \#(Record Dates) & SUPPLY & ONLOAN & $F E E$ & UTILIZATION \\
\hline No & 6,756 & $-1.73 \%$ & $0.10 \%$ & 0.92 & $1.64 \%$ \\
\hline Yes & 659 & $-0.80 \%$ & $-0.21 \%$ & 4.45 & $1.13 \%$ \\
\hline FEE $>1000 \mathrm{bps}$ & 79 & $-0.68 \%$ & $-0.29 \%$ & 5.30 & $0.63 \%$ \\
\hline Full Sample & 7415 & $-1.91 \%$ & $0.07 \%$ & 2.40 & $1.78 \%$ \\
\hline
\end{tabular}


Table 3

\section{Descriptive Statistics - Voting Proposals}

The table presents descriptive statistics for 56,220 proxy proposals of Russell 3000 firms in the 2007-2009 period. Panel A shows data for all proposals while Panel B shows voting outcome statistics for different types of nonroutine proposals. VOTES CAST is the percentage of the total votes cast relative to shares outstanding. FOR, $A G A I N S T$, and ABSTAIN are the total number of votes for, against, and abstained for the proposal, respectively, relative to the $B A S E$ by which the proposal outcome is measured (expressed as a percentage). VOTE MARGIN is defined as FOR minus the minimum threshold required for the proposal to pass. Voting outcome variables are winsorized at the $1 \%$-level. In Panel B, Obs. refers to the number of proposal observations and RDATE Obs. refers to the number of record date proposals (there may be multiple proposals on each record date). NON ROUTINE proposals are proposals not relating to operational or uncontested directorships. $M G T$ are management-sponsored proposals. SHDR are shareholder-sponsored proposals. G-INDEX, COMP and CORP CONTROL are, respectively, dummies for anti-takeover, compensation and merger/proxy contest related proposals.

\begin{tabular}{|c|c|c|c|c|c|c|c|}
\hline \multicolumn{8}{|c|}{ Panel A: Voting Outcome for All Proposals } \\
\hline & $\begin{array}{l}\text { Pa } \\
\text { Obs. }\end{array}$ & \multicolumn{2}{|c|}{ Mean } & Median & Std Dev & Min & Max \\
\hline VOTES CAST & 56,220 & \multicolumn{2}{|c|}{$86.62 \%$} & $88.74 \%$ & $9.49 \%$ & $37.42 \%$ & $100 \%$ \\
\hline FOR & 56,220 & \multicolumn{2}{|c|}{$91.86 \%$} & $97.37 \%$ & $14.15 \%$ & $18.94 \%$ & $100 \%$ \\
\hline AGAINST & 56,220 & \multicolumn{2}{|c|}{$7.54 \%$} & $2.48 \%$ & $13.25 \%$ & $0.00 \%$ & $75 \%$ \\
\hline ABSTAIN & 56,220 & \multicolumn{2}{|c|}{$0.41 \%$} & $0.00 \%$ & $1.56 \%$ & $0.00 \%$ & $11.9 \%$ \\
\hline VOTE MARGIN & 56,220 & \multicolumn{2}{|c|}{$70.16 \%$} & $87.10 \%$ & $30.79 \%$ & $-31.37 \%$ & $100 \%$ \\
\hline \multicolumn{8}{|c|}{ Panel B: Voting Outcome by Proposal Type for Non-Routine Proposals } \\
\hline & Obs. & $\begin{array}{c}R D A T E \\
\text { Obs. }\end{array}$ & $\begin{array}{c}\text { VOTES } \\
\text { CAST }\end{array}$ & FOR & AGAINST & ABSTAIN & $\begin{array}{c}\text { VOTE } \\
\text { MARGIN } \\
\end{array}$ \\
\hline NON ROUTINE & 6,887 & 3,719 & $77.65 \%$ & $73.24 \%$ & $23.02 \%$ & $1.86 \%$ & $23.43 \%$ \\
\hline - $\quad M G T$ & 5,127 & 3,717 & $78.82 \%$ & $84.61 \%$ & $11.73 \%$ & $0.97 \%$ & $35.01 \%$ \\
\hline - $\quad S H D R$ & 1,760 & 824 & $74.27 \%$ & $39.99 \%$ & $55.91 \%$ & $4.44 \%$ & $-10.50 \%$ \\
\hline$-\quad C O M P$ & 4,024 & 2,854 & $77.76 \%$ & $80.67 \%$ & $18.02 \%$ & $1.34 \%$ & $30.48 \%$ \\
\hline - $\quad G-I N D E X$ & 1,190 & 1,034 & $79.54 \%$ & $65.23 \%$ & $28.19 \%$ & $1.10 \%$ & $9.96 \%$ \\
\hline - CORP CONTROL & 588 & 371 & $72.31 \%$ & $80.60 \%$ & $14.64 \%$ & $3.53 \%$ & $51.35 \%$ \\
\hline
\end{tabular}


Table 4

\section{Abnormal Lendable Supply, Borrowing Demand and Fees around Proxy Voting Record Dates}

The table presents results from an event study on the effect of proxy voting on equity lendable supply, loan demand and fees in the $(-30,+30)$ days period around 7,415 voting record dates (record date is $\mathrm{t}=0)$. SUPPLY is the percentage of market capitalization available to lend. ONLOAN is the percentage of market capitalization actually borrowed and FEE is the annualized borrowing fees expressed in basis points. RDATE is a dummy equal to one on the record dates. Control variables comprise governance index (GOV41), institutional ownership (INST), concentration of institutional ownership as measured by the Herfindahl index (INST CONC), the natural log of market capitalization (SIZE), book to market (BM), stock turnover (TURNOVER), bid-ask spread (SPREAD), a small firm dummy (PRICE<\$5), and Short-Term Mom and Long-Term Mom are defined as the cumulative returns in the previous 5 and 252 days, respectively. All regressions include year and firm fixed-effects and robust standard errors clustered at the firm-level, presented in parentheses. *** $(* * *)$ indicates significance at the $1 \%(5 \%, 10 \%)$ level.

\begin{tabular}{|c|c|c|c|c|c|}
\hline & \multicolumn{5}{|c|}{ Dependent Variable } \\
\hline & \multicolumn{2}{|c|}{ SUPPLY } & \multicolumn{2}{|c|}{ ONLOAN } & \multirow{2}{*}{$\begin{array}{c}F E E \\
\text { (5) }\end{array}$} \\
\hline & (1) & (2) & (3) & (4) & \\
\hline FEE & & $\begin{array}{c}-0.0011 * * \\
{[0.000]}\end{array}$ & & $\begin{array}{c}0.0034 * * * \\
{[0.000]}\end{array}$ & \\
\hline RDATE & $\begin{array}{c}-1.6358 * * * \\
{[0.036]}\end{array}$ & $\begin{array}{c}-1.6337 * * * \\
{[0.036]}\end{array}$ & $\begin{array}{c}0.0822 * * * \\
{[0.010]}\end{array}$ & $\begin{array}{c}0.0760 * * * \\
{[0.010]}\end{array}$ & $\begin{array}{c}1.7755 * * * \\
{[0.330]}\end{array}$ \\
\hline INST & $\begin{array}{c}22.8365^{* * * *} \\
{[0.896]}\end{array}$ & $\begin{array}{c}22.9008 * * * \\
{[0.896]}\end{array}$ & $\begin{array}{c}12.2682 * * * \\
{[0.618]}\end{array}$ & $\begin{array}{c}12.0799 * * * \\
{[0.598]}\end{array}$ & $\begin{array}{c}54.6799 * * \\
{[23.860]}\end{array}$ \\
\hline SIZE & $\begin{array}{c}0.6895^{* * * *} \\
{[0.202]}\end{array}$ & $\begin{array}{c}0.6940 * * * \\
{[0.202]}\end{array}$ & $\begin{array}{c}0.2138 \\
{[0.135]}\end{array}$ & $\begin{array}{c}0.2004 \\
{[0.132]}\end{array}$ & $\begin{array}{l}3.0226 \\
{[5.661]}\end{array}$ \\
\hline$B M$ & $\begin{array}{c}0.4482 * * * \\
{[0.158]}\end{array}$ & $\begin{array}{c}0.4623 * * * \\
{[0.160]}\end{array}$ & $\begin{array}{c}0.0830 \\
{[0.104]}\end{array}$ & $\begin{array}{c}0.0407 \\
{[0.101]}\end{array}$ & $\begin{array}{c}9.2589 \\
{[6.134]}\end{array}$ \\
\hline TURNOVER & $\begin{array}{c}0.1307 * * * \\
{[0.031]}\end{array}$ & $\begin{array}{c}0.1339 * * * \\
{[0.031]}\end{array}$ & $\begin{array}{c}0.3736 * * * \\
{[0.022]}\end{array}$ & $\begin{array}{c}0.3638 * * * \\
{[0.021]}\end{array}$ & $\begin{array}{c}2.3021 * * \\
{[0.963]}\end{array}$ \\
\hline SPREAD & $\begin{array}{c}-0.0574 \\
{[0.040]}\end{array}$ & $\begin{array}{c}-0.0589 \\
{[0.040]}\end{array}$ & $\begin{array}{c}-0.0323 \\
{[0.023]}\end{array}$ & $\begin{array}{l}-0.0286 \\
{[0.022]}\end{array}$ & $\begin{array}{r}-0.1665 \\
{[1.623]}\end{array}$ \\
\hline$P R I C E<\$ 5$ & $\begin{array}{c}0.4390 * * \\
{[0.206]}\end{array}$ & $\begin{array}{c}0.4495 * * \\
{[0.206]}\end{array}$ & $\begin{array}{c}-0.5344 * * * \\
{[0.135]}\end{array}$ & $\begin{array}{c}-0.5662 * * * \\
{[0.132]}\end{array}$ & $\begin{array}{l}5.0738 \\
{[6.771]}\end{array}$ \\
\hline Short-Term Mom & $\begin{array}{c}-0.0158 * * * \\
{[0.002]}\end{array}$ & $\begin{array}{c}-0.0158 * * * \\
{[0.002]}\end{array}$ & $\begin{array}{c}-0.0026 * * * \\
{[0.001]}\end{array}$ & $\begin{array}{c}-0.0026 * * * \\
{[0.001]}\end{array}$ & $\begin{array}{l}-0.0207 \\
{[0.045]}\end{array}$ \\
\hline Long-Term Mom & $\begin{array}{c}-0.0026 \\
{[0.002]}\end{array}$ & $\begin{array}{l}-0.0027 \\
{[0.002]}\end{array}$ & $\begin{array}{c}-0.0045 * * * \\
{[0.001]}\end{array}$ & $\begin{array}{c}-0.0043 * * * \\
{[0.001]}\end{array}$ & $\begin{array}{c}-0.0357 \\
{[0.050]}\end{array}$ \\
\hline GOV41 & $\begin{array}{c}9.8038 * * * \\
{[1.875]}\end{array}$ & $\begin{array}{c}9.7859 * * * \\
{[1.873]}\end{array}$ & $\begin{array}{c}-7.0214 * * * \\
{[1.221]}\end{array}$ & $\begin{array}{c}-7.0181 * * * \\
{[1.204]}\end{array}$ & $\begin{array}{l}-20.2775 \\
{[41.791]}\end{array}$ \\
\hline PASSIVE & $\begin{array}{c}15.9453 * * * \\
{[1.519]}\end{array}$ & $\begin{array}{c}15.8619 * * * \\
{[1.525]}\end{array}$ & $\begin{array}{c}-0.6034 \\
{[0.962]}\end{array}$ & $\begin{array}{r}-0.3855 \\
{[0.933]}\end{array}$ & $\begin{array}{c}-72.0027 * \\
{[40.268]}\end{array}$ \\
\hline INST CONC & $\begin{array}{c}-24.1798 * * * \\
{[2.614]}\end{array}$ & $\begin{array}{c}-23.9192 * * * \\
{[2.619]}\end{array}$ & $\begin{array}{l}-1.6306 \\
{[1.536]}\end{array}$ & $\begin{array}{l}-2.3999 \\
{[1.483]}\end{array}$ & $\begin{array}{c}246.3017 * * * \\
{[82.562]}\end{array}$ \\
\hline Hedging Demand & $\begin{array}{c}0.2966 \\
{[0.247]}\end{array}$ & $\begin{array}{l}0.2452 \\
{[0.247]}\end{array}$ & $\begin{array}{c}-0.0242 * * \\
{[0.010]}\end{array}$ & $\begin{array}{c}-0.0231^{* *} \\
{[0.010]}\end{array}$ & $\begin{array}{c}-38.7274 * * * * \\
{[11.901]}\end{array}$ \\
\hline SUE & $\begin{array}{l}0.7869 \\
{[4.447]}\end{array}$ & $\begin{array}{l}0.4197 \\
{[4.467]}\end{array}$ & $\begin{array}{c}-6.2332 * * \\
{[2.805]}\end{array}$ & $\begin{array}{c}-5.0768 * \\
{[2.668]}\end{array}$ & $\begin{array}{c}-345.9800 * * \\
{[154.770]}\end{array}$ \\
\hline ACCRUALS & $\begin{array}{c}-0.6254 \\
{[1.225]}\end{array}$ & $\begin{array}{l}-0.5947 \\
{[1.224]}\end{array}$ & $\begin{array}{c}1.5697 * * \\
{[0.730]}\end{array}$ & $\begin{array}{c}1.4662 * * \\
{[0.711]}\end{array}$ & $\begin{array}{l}16.2272 \\
{[38.044]}\end{array}$ \\
\hline Constant & $\begin{array}{r}-3.0902 \\
{[2.013]} \\
\end{array}$ & $\begin{array}{r}-3.1017 \\
{[2.011]} \\
\end{array}$ & $\begin{array}{l}-1.6785 \\
{[1.367]} \\
\end{array}$ & $\begin{array}{l}-1.5455 \\
{[1.338]} \\
\end{array}$ & $\begin{array}{c}-3.4367 \\
{[55.918]}\end{array}$ \\
\hline Firm FE & Yes & Yes & Yes & Yes & Yes \\
\hline Year FE & Yes & Yes & Yes & Yes & Yes \\
\hline Adj. $R^{2}$ & 0.90 & 0.90 & 0.77 & 078 & 0.75 \\
\hline \# of Firms & 3,053 & 3,053 & 3,053 & 3,053 & 3,053 \\
\hline
\end{tabular}


Table 5

\section{Lendable Supply and Borrowing Demand around Voting Record Dates}

The table presents our main second stage results using the instrumented fee estimated in the first stage to control for the endogeneity of the fee. SUPPLY is the percentage of market capitalization available to lend. ONLOAN is the percentage of market capitalization actually borrowed. FEE is the annualized borrowing fee expressed in basis points, RDATE is a variable equal to one at record date, zero otherwise. Control variables include institutional ownership (INST), the institutional ownership concentration (INST CONC), the natural logarithm of market capitalization (SIZE), book to market (BM), stock turnover (TURNOVER), bid-ask spread (SPREAD), a small firm dummy (PRICE<\$5), cumulative returns in the previous 5 days (Short-Term Mom), cumulative returns in the previous 252 days (Long-Term Mom), and the internal governance measure (GOV41). Hedging Demand is defined as the equal-weighted cumulative return in the past 252 days of related firms with the same four-digit-GICS industry classification. VVOTE is defined as the ratio of between the RDATE and RDATE*FEE coefficients as shown in Section 3. The significance of VVOTE is computed using the delta method. All regressions include year and firm fixed-effects and robust standard errors clustered at the firm and year level, presented in parentheses. $* * *(* * *)$ indicates significance at the $1 \%(5 \%, 10 \%)$ level.

\begin{tabular}{|c|c|c|c|c|}
\hline & \multicolumn{4}{|c|}{ Dependent Variable } \\
\hline & \multicolumn{2}{|c|}{ SUPPLY } & \multicolumn{2}{|c|}{ ONLOAN } \\
\hline & (1) & (2) & (3) & (4) \\
\hline \multirow[t]{2}{*}{ FEE } & -0.0061 & -0.0056 & -0.0045 & -0.0045 \\
\hline & {$[0.006]$} & {$[0.006]$} & {$[0.006]$} & [0.006] \\
\hline \multirow[t]{2}{*}{$R D A T E^{*} F E E$} & & $0.0074 *$ & & $-0.0015 * * *$ \\
\hline & & [0.004] & & [0.000] \\
\hline \multirow[t]{2}{*}{ RDATE } & $-1.6250 * * *$ & $-1.9874 * * *$ & $0.0903 * * *$ & $0.1637 * * *$ \\
\hline & [0.038] & [0.207] & {$[0.016]$} & [0.024] \\
\hline \multirow[t]{2}{*}{ INST } & $23.1808 * * *$ & $21.4098 * * *$ & $12.5380 * * *$ & $12.5378 * * *$ \\
\hline & [0.960] & [0.949] & {$[0.675]$} & [0.675] \\
\hline \multirow[t]{2}{*}{ SIZE } & $0.7046 * * *$ & $0.9696 * * *$ & $0.2539 *$ & $0.2540 *$ \\
\hline & {$[0.206]$} & [0.203] & {$[0.144]$} & {$[0.144]$} \\
\hline \multirow[t]{2}{*}{$B M$} & $0.5153 * * *$ & $0.3795 * *$ & 0.1124 & 0.1125 \\
\hline & [0.182] & {$[0.181]$} & {$[0.133]$} & [0.133] \\
\hline \multirow{2}{*}{ TURNOVER } & $0.1448 * * *$ & $0.0932 * * *$ & $0.3844 * * *$ & $0.3843 * * *$ \\
\hline & [0.034] & [0.033] & [0.028] & [0.028] \\
\hline \multirow[t]{2}{*}{ SPREAD } & -0.0585 & $-0.1390 * * *$ & -0.0305 & -0.0307 \\
\hline & {$[0.042]$} & {$[0.041]$} & {$[0.027]$} & [0.027] \\
\hline \multirow[t]{2}{*}{$P R I C E<\$ 5$} & $0.4684 * *$ & $0.5011^{* *}$ & $-0.5257 * * *$ & $-0.5260 * * *$ \\
\hline & {$[0.210]$} & [0.206] & {$[0.150]$} & {$[0.150]$} \\
\hline \multirow[t]{2}{*}{ Short-Term Mom } & $-0.0160 * * *$ & $-0.0193 * * *$ & $-0.0028 * * *$ & $-0.0027 * * *$ \\
\hline & [0.002] & [0.002] & [0.001] & [0.001] \\
\hline \multirow{2}{*}{ Long-Term Mom } & -0.0028 & 0.0030 & $-0.0050 * * *$ & $-0.0050 * * *$ \\
\hline & [0.002] & {$[0.002]$} & [0.001] & [0.001] \\
\hline \multirow[t]{2}{*}{ GOV41 } & $9.6655 * * *$ & 2.7658 & $-7.1928 * * *$ & $-7.1926 * * *$ \\
\hline & [1.875] & [1.848] & [1.273] & [1.273] \\
\hline \multirow[t]{2}{*}{ INST CONC } & $-22.6961 * * *$ & $-22.3641 * * *$ & & \\
\hline & [3.135] & [3.046] & & \\
\hline \multirow[t]{2}{*}{ PASSIVE } & $15.5213 * * *$ & $7.1410^{* * *}$ & & \\
\hline & [1.670] & [1.602] & & \\
\hline Hedging Demand & & & $\begin{array}{c}-0.0262 * * \\
{[0.011]}\end{array}$ & $\begin{array}{c}-0.0262 * * \\
{[0.011]}\end{array}$ \\
\hline \multirow[t]{2}{*}{$S U E$} & & & $-1.6317 * * *$ & $-1.6316^{* * *}$ \\
\hline & & & {$[0.578]$} & {$[0.578]$} \\
\hline Firm FE & Yes & Yes & Yes & Yes \\
\hline Year FE & Yes & Yes & Yes & Yes \\
\hline Kleibergen-Paap rk LM & 13.54 & 26.55 & 9.54 & 9.92 \\
\hline $\begin{array}{l}\text { P-Value } \\
\text { P- }\end{array}$ & 0.001 & 0.000 & 0.001 & 0.019 \\
\hline Cragg-Donald Wald F & 1727.85 & 416.89 & 968.33 & 484.16 \\
\hline Sargan-Hansen Statistic & 0.145 & 0.94 & 1.047 & 1.21 \\
\hline P-Value & 0.703 & 0.624 & 0.306 & 0.547 \\
\hline
\end{tabular}


Table 6

Institutional Ownership Composition and Equity Lending Activity on the Record Date

The table reports the coefficients for the RDATE dummy variable using the instrumental variables framework similar to Table 5, where RDATE is conditional on below (Low) and above (High) median for several ownership structure characteristics. SUPPLY is the percentage of market capitalization available to lend. ONLOAN is the percentage of market capitalization actually borrowed. RDATE is a dummy equal to one on the record dates. Panel A uses total institutional ownership, Panel B uses blockholders defined as those institutional investors with above 5\% of market capitalization, Panel $\mathrm{C}$ focuses on blockholdings owned by mutual funds, Panel D for those held by banks and insurance companies, Panel E by Pension and Endowment Funds, and Panel F for long-term blockholders based on Chen, Harford and Li (2007). Regressions include the high/low variable of interest where this is not included in the main specification. All regressions include year and firm fixed-effects and robust standard errors clustered at the firm and year level. Diff captures the difference between High and Low estimates. We report p-values in parentheses. *** $(* * *)$ indicates significance at the $1 \%(5 \%, 10 \%)$ level.

\begin{tabular}{|c|c|c|c|}
\hline Lending Variable & High & Low & Diff $(P$-value $)$ \\
\hline \multicolumn{4}{|c|}{ Panel A: Institutional Ownership } \\
\hline SUPPLY & $\begin{array}{c}-1.961 * * * \\
(0.182)\end{array}$ & $\begin{array}{c}-2.067 * * * \\
(0.375)\end{array}$ & $\begin{array}{c}0.107 \\
(0.613)\end{array}$ \\
\hline ONLOAN & $\begin{array}{c}0.170 * * * \\
(0.023) \\
\end{array}$ & $\begin{array}{c}0.146 * * * \\
(0.033) \\
\end{array}$ & $\begin{array}{c}0.024 \\
(0.329)\end{array}$ \\
\hline \multicolumn{4}{|c|}{ Panel B: All Blockholders } \\
\hline$S U P P L Y$ & $\begin{array}{c}-2.915 * * * * \\
(0.435)\end{array}$ & $\begin{array}{c}-1.688^{* * * *} \\
(0.142)\end{array}$ & $\begin{array}{c}-1.227 * * * \\
(0.000)\end{array}$ \\
\hline ONLOAN & $\begin{array}{c}0.194 * * * \\
(0.058)\end{array}$ & $\begin{array}{c}0.163 * * * \\
(0.023)\end{array}$ & $\begin{array}{c}0.031 \\
(0.487)\end{array}$ \\
\hline \multicolumn{4}{|c|}{ Panel C: Mutual Fund Blockholders } \\
\hline SUPPLY & $\begin{array}{c}-2.530 * * * \\
(0.271)\end{array}$ & $\begin{array}{c}-1.580 * * * \\
(0.159)\end{array}$ & $\begin{array}{c}-0.949 * * * \\
(0.000)\end{array}$ \\
\hline ONLOAN & $\begin{array}{c}0.161 * * * \\
(0.036)\end{array}$ & $\begin{array}{c}0.169 * * * \\
(0.023)\end{array}$ & $\begin{array}{c}-0.008 \\
(0.775)\end{array}$ \\
\hline \multicolumn{4}{|c|}{ Panel D: Bank and Insurance Companies Blockholders } \\
\hline SUPPLY & $\begin{array}{c}-2.279 * * * \\
(0.229)\end{array}$ & $\begin{array}{c}-1.803 * * * \\
(0.197)\end{array}$ & $\begin{array}{c}-0.476 * * * \\
(0.000)\end{array}$ \\
\hline ONLOAN & $\begin{array}{c}0.167 * * * \\
(0.025) \\
\end{array}$ & $\begin{array}{c}0.162 * * * \\
(0.029) \\
\end{array}$ & $\begin{array}{c}0.004 \\
(0.839) \\
\end{array}$ \\
\hline \multicolumn{4}{|c|}{ Panel E: Pension and Endowment Blockholdings } \\
\hline SUPPLY & $\begin{array}{c}-2.450 * * * \\
(0.374)\end{array}$ & $\begin{array}{c}-1.909 * * * \\
(0.184)\end{array}$ & $\begin{array}{c}-0.541 * * * \\
(0.013)\end{array}$ \\
\hline ONLOAN & $\begin{array}{c}0.209 * * * * \\
(0.087)\end{array}$ & $\begin{array}{c}0.164 * * * \\
(0.024)\end{array}$ & $\begin{array}{c}0.045 \\
(0.565) \\
\end{array}$ \\
\hline \multicolumn{4}{|c|}{ Panel F: Long-Term Blockholders (based on Chen et al. (2007)) } \\
\hline SUPPLY & $\begin{array}{c}-2.401 * * * \\
(0.189)\end{array}$ & $\begin{array}{c}-1.736^{* * * *} \\
(0.332)\end{array}$ & $\begin{array}{c}-0.665^{* * *} \\
(0.007)\end{array}$ \\
\hline ONLOAN & $\begin{array}{c}0.155^{* * * *} \\
(0.024) \\
\end{array}$ & $\begin{array}{c}0.172 * * * \\
(0.028) \\
\end{array}$ & $\begin{array}{l}-0.017 \\
(0.444) \\
\end{array}$ \\
\hline
\end{tabular}


Table 7

\section{Firm Characteristics, Proposal Types and Equity Lending Activity on the Record Date}

The table reports the coefficients for the RDATE dummy variable using the instrumental variables framework similar to Table 5, with the sample split into below (Low) and above (High) median for several firm characteristics and proposal type. SUPPLY is the percentage of market capitalization available to lend. ONLOAN is the percentage of market capitalization actually borrowed. RDATE is a dummy equal to one on the record dates. Panel A is based on the GOV41 measure of internal corporate governance; Panel B uses cumulative returns in the previous twelve months; Panel C is based on stock market capitalization; Panel D is based on non-routine proposals; Panel E on compensation proposals referring to those related to managerial compensation policies; Panel F on the G-INDEX of anti-takeover provisions (Gompers, Ishi, and Metrick (2003)); and Panel G is based on corporate control proposals defined as those record dates with a proxy contest or merger. All regressions include year and firm fixed-effects and robust standard errors clustered at the firm and year level. Diff captures the difference between Low and High estimates in Panels A to C and With Proposal and Without Proposal in Panels $\mathrm{D}$ to $\mathrm{G}$. We report p-values in parentheses. $* * *(* * *)$ indicates significance at the $1 \%(5 \%, 10 \%)$ level.

\begin{tabular}{|c|c|c|c|}
\hline Lending Variable & Low & High & Diff (P-value $)$ \\
\hline \multicolumn{4}{|c|}{ Panel A: Corporate Governance } \\
\hline$S U P P L Y$ & $\begin{array}{c}-2.446 * * * \\
(0.252)\end{array}$ & $\begin{array}{c}-1.727 * * * \\
(0.183)\end{array}$ & $\begin{array}{c}-0.719 * * * \\
(0.000)\end{array}$ \\
\hline ONLOAN & $\begin{array}{c}0.188 * * * \\
(0.055)\end{array}$ & $\begin{array}{c}0.155^{* * * *} \\
(0.023)\end{array}$ & $\begin{array}{c}0.033 \\
(0.575)\end{array}$ \\
\hline \multicolumn{4}{|c|}{ Panel B: Previous Twelve Month Returns } \\
\hline SUPPLY & $\begin{array}{c}-2.145 * * * \\
(0.251)\end{array}$ & $\begin{array}{c}-1.912 * * * \\
(0.179)\end{array}$ & $\begin{array}{c}-0.233 * * \\
(0.029)\end{array}$ \\
\hline ONLOAN & $\begin{array}{c}0.229 * * * \\
(0.037)\end{array}$ & $\begin{array}{c}0.106^{* * * *} \\
(0.026)\end{array}$ & $\begin{array}{c}0.123 \\
(0.004)\end{array}$ \\
\hline \multicolumn{4}{|c|}{ Panel C: Size } \\
\hline SUPPLY & $\begin{array}{c}-3.155^{* * * *} \\
(0.315)\end{array}$ & $\begin{array}{c}-1.255^{* * * *} \\
(0.117)\end{array}$ & $\begin{array}{c}-1.900 * * * \\
(0.000)\end{array}$ \\
\hline ONLOAN & $\begin{array}{c}0.152 * * * \\
(0.043)\end{array}$ & $\begin{array}{c}0.168 * * * \\
(0.022) \\
\end{array}$ & $\begin{array}{l}-0.026 \\
(0.670) \\
\end{array}$ \\
\hline Lending Variable & With Proposal & Without Proposal & Diff (P-value $)$ \\
\hline \multicolumn{4}{|c|}{ Panel D: Non-Routine } \\
\hline SUPPLY & $\begin{array}{c}-2.307 * * * \\
(0.235)\end{array}$ & $\begin{array}{c}-2.188 * * * \\
(0.215)\end{array}$ & $\begin{array}{c}-0.119^{*} \\
(0.077)\end{array}$ \\
\hline ONLOAN & $\begin{array}{c}0.161 * * * \\
(0.033)\end{array}$ & $\begin{array}{c}0.176^{* * *} \\
(0.033)\end{array}$ & $\begin{array}{l}-0.015 \\
(0.498)\end{array}$ \\
\hline \multicolumn{4}{|c|}{ Panel E: Compensation-related } \\
\hline SUPPLY & $\begin{array}{c}-2.608 * * * \\
(0.269)\end{array}$ & $\begin{array}{c}-2.184 * * * \\
(0.219)\end{array}$ & $\begin{array}{c}-0.424 * * * \\
(0.009)\end{array}$ \\
\hline ONLOAN & $\begin{array}{l}0.153 * \\
(0.093)\end{array}$ & $\begin{array}{c}0.153^{* * *} \\
(0.033) \\
\end{array}$ & $\begin{array}{c}0.001 \\
(0.994) \\
\end{array}$ \\
\hline \multicolumn{4}{|c|}{ Panel F: G-Index } \\
\hline SUPPLY & $\begin{array}{c}-2.666 * * * \\
(0.413)\end{array}$ & $\begin{array}{c}-2.394 * * * \\
(0.317)\end{array}$ & $\begin{array}{l}-0.272 * \\
(0.084)\end{array}$ \\
\hline ONLOAN & $\begin{array}{c}0.074 \\
(0.062) \\
\end{array}$ & $\begin{array}{l}0.093 * \\
(0.051) \\
\end{array}$ & $\begin{array}{l}-0.019 \\
(0.806)\end{array}$ \\
\hline \multicolumn{4}{|c|}{ Panel G: Mergers and Proxy Contests } \\
\hline$S U P P L Y$ & $\begin{array}{l}-2.774 * * * \\
-0.400\end{array}$ & $\begin{array}{c}-1.995 * * * \\
-0.265\end{array}$ & $\begin{array}{c}-0.779 * * \\
(0.032)\end{array}$ \\
\hline ONLOAN & $\begin{array}{c}0.306^{* *} \\
(0.149)\end{array}$ & $\begin{array}{l}0.183^{*} \\
(0.095)\end{array}$ & $\begin{array}{c}0.123 \\
(0.188)\end{array}$ \\
\hline
\end{tabular}


Table 8

Voting Outcome

The table presents results from a regressions analysis of voting outcome for non-routine proposals. The dependent variable is VOTES FOR, the percentage of votes FOR the proposal. NON ROUTINE proposals are defined by NYSE Rule 452 as those in which broker voting is not allowed. Columns (1) - (2) present results for all voting; Column (3) presents results only for mutual funds voting. The independent variables are: $\triangle S U P P L Y$ and $\triangle O N L O A N$, the change in lendable supply and on loan from days ( $\mathrm{t}=-30$ to -20$)$ to record date $(\mathrm{t}=0)$. DSHR is a dummy equal to one if shareholders sponsor the proposal, zero otherwise. DISS is a dummy equal to 1 when management is in favor and ISS is against the proposal. DSHR equals one for shareholder-sponsored proposals. G-INDEX, COMP and CORP CONTROL are, respectively, dummies for anti-takeover, compensation and merger/proxy contest related proposals All estimations include proposal fixed effects and firm-level controls. Control variables include governance (GOV41), institutional ownership (INST), concentration of institutional ownership as measured by the Herfindahl index (INST CONC), the natural logarithm of market capitalization (SIZE), book to market $(B M)$, stock turnover (TURNOVER), bid-ask spread (SPREAD), a small firm dummy (PRICE<\$5), and prior twelve-month return $(R E T U R N)$. All regressions include year and firm fixed-effects and robust standard errors clustered at the firm level (firm-record date level in column (3)), presented in parentheses. $* * *(* * *)$ indicates significance at the $1 \%$ $(5 \%, 10 \%)$ level.

\begin{tabular}{|c|c|c|c|}
\hline & \multicolumn{3}{|c|}{ Dependent Variable: \% of Votes FOR proposal } \\
\hline & \multicolumn{2}{|c|}{ All Voting } & \multirow{2}{*}{$\begin{array}{c}\text { Voting by Mutual Funds } \\
(3)\end{array}$} \\
\hline & (1) & $(2)$ & \\
\hline \multirow{2}{*}{$\triangle S U P P L Y$} & $0.350^{*}$ & -0.103 & $-0.795^{* *}$ \\
\hline & $(0.218)$ & $(0.333)$ & $(0.322)$ \\
\hline \multirow[t]{2}{*}{$\triangle O N L O A N$} & 0.151 & 0.711 & \\
\hline & $(0.413)$ & $(0.726)$ & \\
\hline \multirow[t]{2}{*}{ DISS } & & $-19.831 * * *$ & $-49.218 * * *$ \\
\hline & & $(1.182)$ & $(0.798)$ \\
\hline \multirow[t]{2}{*}{ COMP } & & $11.050^{* * *}$ & 0.133 \\
\hline & & $(0.982)$ & $(0.702)$ \\
\hline \multirow[t]{2}{*}{$G-I N D E X$} & & $11.297 * * *$ & $9.984 * * *$ \\
\hline & & (1.409) & $(1.514)$ \\
\hline \multirow{2}{*}{ CORP CONTROL } & & $9.333 * * *$ & $9.393 * * *$ \\
\hline & & (2.095) & $(1.175)$ \\
\hline \multirow[t]{2}{*}{$D S H R$} & $-43.595 * * *$ & $-42.660 * * *$ & $-36.987 * * *$ \\
\hline & $(1.781)$ & $(1.761)$ & $(0.961)$ \\
\hline \multirow[t]{2}{*}{$\triangle S U P P L Y * D I S S$} & & $1.545 * * *$ & $1.178 * * *$ \\
\hline & & $(0.395)$ & $(0.272)$ \\
\hline \multirow{2}{*}{$\triangle S U P P L Y * C O M P$} & & $1.859 * * *$ & $0.466^{*}$ \\
\hline & & $(0.445)$ & $(0.304)$ \\
\hline \multirow[t]{2}{*}{$\triangle S U P P L Y * G-I N D E X$} & & $1.642 * * *$ & $1.233 * *$ \\
\hline & & $(0.550)$ & $(0.593)$ \\
\hline \multirow[t]{2}{*}{$\triangle S U P P L Y * C O R P C O N T$} & & $2.131^{* *}$ & 0.380 \\
\hline & & $(0.870)$ & $(0.406)$ \\
\hline \multirow[t]{2}{*}{$\triangle S U P P L Y * D S H R$} & $-2.444 * * *$ & $-1.997 * * *$ & 0.162 \\
\hline & $(0.556)$ & $(0.569)$ & $(0.342)$ \\
\hline \multirow[t]{2}{*}{$\triangle O N L O A N * D I S S$} & & $-2.269 * *$ & \\
\hline & & $(0.952)$ & \\
\hline \multirow[t]{2}{*}{$\triangle O N L O A N * C O M P$} & & -0.989 & \\
\hline & & $(1.151)$ & \\
\hline \multirow[t]{2}{*}{$\triangle O N L O A N * G-I N D E X$} & & -1.632 & \\
\hline & & $(1.429)$ & \\
\hline \multirow[t]{2}{*}{$\triangle O N L O A N * C O R P C O N T$} & & -0.644 & \\
\hline & & (1.907) & \\
\hline \multirow[t]{2}{*}{$\triangle O N L O A N * D S H R$} & 0.280 & 0.320 & \\
\hline & $(1.563)$ & $(1.641)$ & \\
\hline Firm FE & Yes & Yes & Yes \\
\hline Fund Family FE & No & No & Yes \\
\hline Observations & 6,887 & 6,887 & $1,524,290$ \\
\hline Adjusted $\mathrm{R}^{2}$ & 0.599 & 0.727 & 0.791 \\
\hline
\end{tabular}


Appendix A: Figures

How Does Equity Lending Work?

Figure A1

US Securities \$100

US Securities $\$ 100$

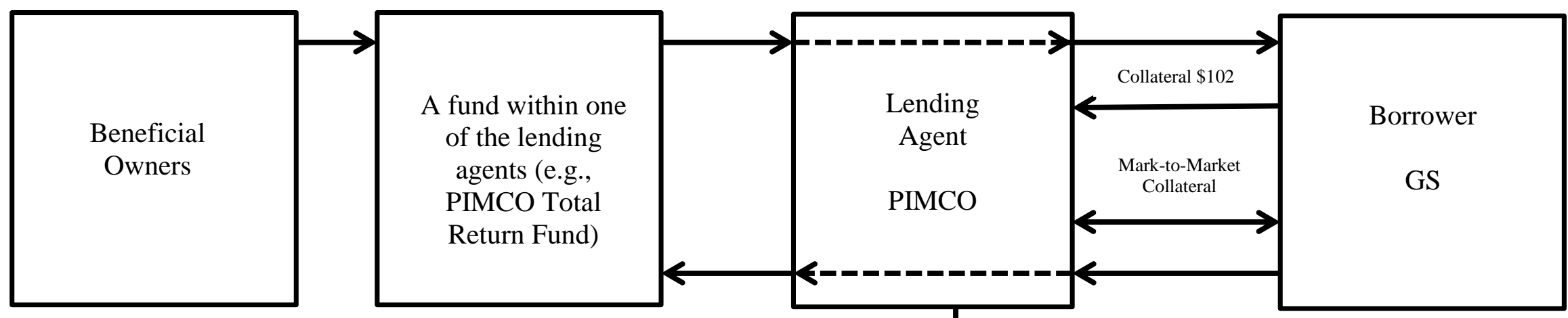

Dividends \& other entitlements

Dividends \& other

entitlements

Cash Investment Vehicle

- Borrower leaves collateral with lending agent (e.g., State Street) and pays a fee for the loan.

- Lender still receives dividends but loses voting rights; borrower gets voting rights. 


\section{Appendix A: Tables}

Table AI

Cash Flows on a Securities Loan with Cash Collateral

\begin{tabular}{|ll}
\hline Settlement date & June 30 th \\
Term & Open \\
Security & XYZ Limited \\
Security price & $\$ 10.00$ per share \\
Quantity & 100,000 shares \\
Loan value & $\$ 1,000,000.00$ \\
Rebate rate & 80 basis points \\
Collateral & Cash \\
Margin required & $2 \%$ \\
Collateral required & $\$ 1,020,000.00$ \\
Reinvestment rate & 130 basis points \\
Daily lending income & $\$ 13.97(\$ 1,020,000.00 * 0.005 *(1 / 365))$ \\
Daily Rebate & $\$ 22.36(\$ 1,020,000 * 0.008 *(1 / 365))$ \\
\end{tabular}

Assumption: No change in value, therefore no change due to daily mark to market, and no change in terms.

Payments to the borrower:

On July 30th $\$ 670.80(\$ 22.36 * 30$ days $)$

Profit for the lender:

On July 30th $\$ 419.10(\$ 13.97 * 30$ days $)$

Source: Adapted from “An Introduction to Securities Lending,” Spitalfields Advisors Limited, 2006. 
${ }^{1}$ The record date determines the ownership date for voting purposes. The record date is set prior to the date of the shareholder meeting, when the voting takes place. Most states (for example, California and Delaware) require that the record date be set at a maximum of 60 days and a minimum of ten days prior to the meeting; New York sets the maximum at 50 days.

${ }^{2}$ We use the terms recall and restrict interchangeably, capturing both recall of shares actually on loan, and restriction on shares available to lend that that have not been borrowed.

${ }^{3}$ Edmans (2014) surveys the literature on blockholders and discusses the different incentives and costs faced by blockholders when deciding how to exert governance.

${ }^{4}$ The securities lending process is shown graphically, and with a numerical example of cash flows and fees in Appendix A.

${ }^{5}$ See Hu and Black (2006) for a discussion of empty voting.

${ }^{6}$ See http://www.riskmetrics.com/press/articles/040307boardiq.html

${ }^{7}$ See https://content.putnam.com/shared/pdf/proxy voting guidelines.pdf

${ }^{8}$ See http://www.tiaa-cref.org/ucm/groups/content/@ap_ucm_p_tcp/documents/document/tiaa01007871.pdf

${ }^{9}$ See http://www.riskmetrics.com/press/articles/040307boardiq.html

${ }^{10}$ We thank securities lending practitioners at J.P. Morgan and Goldman Sachs for helping us understand industry practices for recalling and restricting lendable shares.

${ }^{11} \mathrm{Hu}$ and Black (2008) discuss the case of Fidelity and Morgan Stanley, who together held 10\% shares of Telecom Italia and led a campaign against a takeover of Pirelli. However, they were only able to vote $1 \%$ of the shares because the remaining shares were lent out and could not be called in in time for the vote. The Pirelli bid was approved.

${ }^{12}$ See Bushee (1998, 2001), Bushee, Carter, and Gerakos (2013), and Chen, Harford, and Lee (2007) for more details.

${ }^{13}$ Our conclusions based on groups (2) to (5) are unaffected if we use total ownership instead of blockholdings.

${ }^{14}$ Note that we also must have a first-stage equation for $R D A T E^{*} F E E$ because the product of an endogenous variable $(F E E)$ and an exogenous variable (RDATE) is still endogenous (see Wooldridge (2001)).

${ }^{15}$ Note that a reduction in lendable supply includes both the actual recall of shares that are on loan and a reduction in shares made available to lend.

${ }^{16}$ There is a large body of research in the labor economics literature with event studies of regulatory changes on labor supply. For example, Eissa and Liebman (1996), Blundell, Duncan, and Meghir (1998), Meyer and Rosenbaum (2001), Eissa and Hoynes (2004), Blau and Kahn (2007), and Rothstein (2010) study the sensitivity of tax changes on labor supply and market participation. Blundell and Macurdy (1999) provides a comprehensive survey of the labor supply literature. 
${ }^{17}$ In contrast to the activity around voting record dates, we find that around the time of the ex-dividend record date, there is a statistically and economically significant increase in borrowing demand, with little change in the supply of lendable shares.

${ }^{18}$ A similar concept has been used in many fields, such as health care (e.g., Hall and Jones (2007), and Becker and Elias (2007)), marketing (e.g., Miller et al. (2011)) and environmental studies (e.g., Hanemann (1994) and Kling et al. (2012)). For example, Becker and Elias (2007) estimate the following in their study of organ donations: "How much pay is required to induce an individual to sell an organ? We estimate the value or price of an organ from living donors by computing how much additional income or market consumption an individual will require to be indifferent between selling an organ or not.”.

${ }^{19}$ For example, BlackRock has a team of 20 professionals dedicated to corporate governance in eight offices globally (Corporate Governance \& Responsible Investment Report, BlackRock, 2013).

${ }^{20}$ FOR is defined as the percentage of number of FOR votes, relative to the base by which the proposal is decided. The base varies by proposal, and can be the sum of FOR, AGAINST, and ABSTAIN votes, the sum of FOR and AGAINST votes, or the number of shares outstanding, for example.

${ }^{21}$ We present OLS estimations to ensure that distributional assumptions do not unduly affect our results (Angrist and Pischke (2009)). The results are robust to employing logit estimations.

${ }^{22}$ https://advisors.vanguard.com/VGApp/iip/site/advisor/researchcommentary/article/IWE_InvResSecuritiesLending 